\title{
Nordihydroguaiaretic Acid Attenuates the Oxidative Stress-Induced Decrease of CD33 Expression in Human Monocytes
}

\author{
Silvia Guzmán-Beltrán, ${ }^{1}$ José Pedraza-Chaverri, ${ }^{2}$ Susana Gonzalez-Reyes, ${ }^{2}$ \\ Fernando Hernández-Sánchez, ${ }^{1}$ Ulises E. Juarez-Figueroa, ${ }^{1}$ Yolanda Gonzalez, ${ }^{1}$ \\ Karen Bobadilla, ${ }^{1}$ and Martha Torres ${ }^{1}$ \\ ${ }^{1}$ Departamento de Microbiología en Investigación, Instituto Nacional de Enfermedades Respiratorias, \\ Ismael Cosío Villegas, Calzada de Tlalpan 4502, Sección XVI, 14080 México, DF, Mexico \\ ${ }^{2}$ Departamento de Biología, Facultad de Química, Universidad Nacional Autónoma de México (UNAM), \\ Ciudad Universitaria, 04510 México, DF, Mexico
}

Correspondence should be addressed to Martha Torres; marthatorres98@yahoo.com

Received 12 October 2012; Revised 21 December 2012; Accepted 29 December 2012

Academic Editor: Narasimham L. Parinandi

Copyright (C) 2013 Silvia Guzmán-Beltrán et al. This is an open access article distributed under the Creative Commons Attribution License, which permits unrestricted use, distribution, and reproduction in any medium, provided the original work is properly cited.

Nordihydroguaiaretic acid (NDGA) is a natural lignan with recognized antioxidant and beneficial properties that is isolated from Larrea tridentata. In this study, we evaluated the effect of NDGA on the downregulation of oxidant stress-induced CD33 in human monocytes (MNs). Oxidative stress was induced by iodoacetate (IAA) or hydrogen peroxide $\left(\mathrm{H}_{2} \mathrm{O}_{2}\right)$ and was evaluated using reactive oxygen species (ROS) production, and cell viability. NDGA attenuates toxicity, ROS production and the oxidative stressinduced decrease of CD33 expression secondary to IAA or $\mathrm{H}_{2} \mathrm{O}_{2}$ in human MNs. It was also shown that NDGA $(20 \mu \mathrm{M})$ attenuates cell death in the THP-1 cell line that is caused by treatment with either IAA or $\mathrm{H}_{2} \mathrm{O}_{2}$. These results suggest that NDGA has a protective effect on CD33 expression, which is associated with its antioxidant activity in human MNs.

\section{Introduction}

Nordihydroguaiaretic acid (NDGA) is a natural lignan that is primarily isolated and commercially produced from the desert creosote bush, Larrea tridentata, which has long been used in traditional medicine for the treatment of several illnesses including diabetes and inflammation [1]. It is estimated that NDGA comprises approximately $5 \%$ to $10 \%$ of the dry weight of the leaves, and this corresponds to $80 \%$ of all the phenolic compounds in the resin [2]. Cell culture and animal model studies have demonstrated that NDGA has biological properties, including anticarcinogenic, antidiabetic, antiviral, antioxidant, and anti-inflammatory activities [3].

The beneficial effects of NDGA have been essentially attributed to its antioxidant properties. NDGA is an effective in vitro scavenger of peroxynitrite, singlet oxygen, hydroxyl radical $\left({ }^{\circ} \mathrm{OH}\right)$, and hypochlorous acid $[4,5]$. It has been shown that NDGA is capable of protecting rats that are exposed to oxidative stress induced by ozone, potassium dichromate, and cisplatin [4, 6, 7]. In addition NDGA also protects primary rat neuronal cultures against damage that is generated by hydrogen peroxide $\left(\mathrm{H}_{2} \mathrm{O}_{2}\right)$ and iodoacetate (IAA) [8-10].

Additionally, it has been found that NDGA induces transcription factor Nrf2 and expression of heme oxygenase1 (HO-1) in different kinds of line cells $[9,11]$. In fact, $\mathrm{Nrf} 2$ factor controls the expression of more than 100 genes of cytoprotective proteins including antioxidant enzymes such as HO-1 [11].

On the other hand, it is well established that oxidative stress is implicated in pathologies such as cancer, diabetes, and inflammation. Oxidative stress is an imbalance in the redox state that is generated by exacerbated ROS production or diminished protective systems, such as enzymes or scavenger molecules [12]. In fact, the increased production of 
reactive oxygen species (ROS) causes cell damage and even cell death, and antioxidants may help to prevent or alleviate diseases in which oxidative stress is involved.

Glutathione is the most abundant nonprotein sulfhydryl compound and the major intracellular redox buffer in almost all cells. This molecule constitutes the first line of the cellular defense mechanism against oxidative injury [13]. There are evidences that the intracellular redox status regulates various aspects of cellular function and that glutathione (GSH) is important in immune modulation $[14,15]$. Recently, it has been described in mice that the pretreatment of NDGA before the treatment with the tumor promoting agent 12-Otetradecanoylphorbol-13-acetate (TPA) mitigated cutaneous lipid peroxidation and inhibited $\mathrm{H}_{2} \mathrm{O}_{2}$ production. NDGA also was able to restore GSH level and activities of antioxidant enzymes and even to attenuate inflammation [16].

$\mathrm{H}_{2} \mathrm{O}_{2}$ and IAA are toxic compounds that are utilized commonly to induce oxidative stress in cell models [8-10]. IAA is an alkylating agent that irreversibly inhibits the glycolytic enzyme glyceraldehyde-3-phosphate dehydrogenase (GAPDH) [17]. IAA reduces adenosine triphosphate (ATP) levels and cell survival in a dose-dependent manner [18]. It has been shown that IAA-induced toxicity is related to ROS production, at least in the hippocampal and cerebellar granule neurons of rats [19].

As an ROS, $\mathrm{H}_{2} \mathrm{O}_{2}$ is less reactive; however, it can easily penetrate cell membranes and react with transition metal ions to produce ${ }^{\bullet} \mathrm{OH}$. This intermediary metabolite reacts rapidly and indiscriminately with biomolecules of all classes, including nucleic acids, free nucleotides, proteins, lipids, and carbohydrates. ROS induce oxidative damage, which may cause DNA mutations, protein inactivation, and cell death [12].

In contrast, monocytes (MNs) play a central role in inflammation and host defense against microorganisms. However, in oxidative stress-related diseases, such as diabetes or atherosclerosis, MNs are permanently activated and produce high levels of ROS and the proinflammatory cytokines IL-6, IL-1, and tumor necrosis factor alpha (TNF- $\alpha$ ). This increased ROS production may lead to severe disorders, such as chronic inflammation and even cell death [20].

In this context, it has been suggested that changing glutathione redox status, which is the balance between intracellular reduced (GSH) and oxidized (GSSG) glutathione, in antigen presenting cells (APCs) regulates the helper T-cell type 1 (Th1)/Th2 balance due to the production of IL-12 in mice $[21]$.

In addition, after an oxidative challenge, macrophages, mesangial cells, and monocytes increase the amount of available arachidonic acid, by means of the activation of the phospholipases A (PLA) and C (PLC) [22-24]. The arachidonic acid is the substrate for the synthesis of eicosanoids: prostaglandins (PG), leukotrienes, and thromboxanes, which are involved in the inflammatory responses through the production of IL- 8 and TNF- $\alpha$. The metabolic conversion of arachidonic acid into its byproducts requires the catalytic activity of cyclooxygenase (COX) or lipoxygenase (LOX), and it is known that oxidant molecules can induce the synthesis of the COX through a transcriptional mediated mechanism, involving the $\mathrm{I} \kappa \mathrm{B} \alpha$ degradation and $\mathrm{NF} \kappa \mathrm{B}$ nuclear translocation. Therefore the oxidative stress has a dual role in the eicosanoid production; at one hand it is the signal to increase the substrate availability, and on the other hand it activates the biosynthetic pathway [25].

Moreover, diabetic patients with hyperglycemia present oxidative stress and constant inflammation. This is due to diverse mechanisms that are associated with excessive ROS production, such as the irreversible production of advanced glycation end products (AGEs). AGEs stimulate the production of inflammatory cytokines in monocytes and macrophages [26]. Additionally, hyperglycemia may stimulate the production of inflammatory cytokines, such as IL-6, IL-1, and tumor necrosis factor alpha (TNF- $\alpha$ ), by increasing the levels of peroxides and free radicals and inducing inflammation [27]. Recently, the decreased expression of CD33 has been described in the macrophages of diabetic patients with hyperglycemia. This disorder contributes to the spontaneous secretion of TNF- $\alpha$, and this alteration may promote additional inflammation during the early stages of diabetes mellitus type II [28].

CD33 is a myeloid cell-specific type I transmembrane glycoprotein that is constitutively expressed on the surfaces of both myeloid progenitors and mature monocytes. This molecule is a receptor that belongs to the family of sialic acidbinding immunoglobulin Ig-like lectins (SIGLECS) [29].

In this study, we evaluate the potential protective effect of NDGA on IAA- and $\mathrm{H}_{2} \mathrm{O}_{2}$-induced toxicity in the THP1 cell line and in human MNs. We also demonstrate that NDGA attenuates the oxidant stress-induced CD33 expression downregulation in human MNs.

\section{Materials and Methods}

2.1. MNs and THP-1 Cells. Peripheral blood mononuclear cells were obtained from heparinized venous whole blood by gradient centrifugation over a Ficoll-sodium diatrizoate solution (Lymphoprep, Nycomed Pharma, Oslo, Norway) using standard procedures [30]. The layer containing the peripheral blood mononuclear cells (PBMCs) was harvested, and the MNs were enriched by plastic adherence for $1 \mathrm{~h}$ at $37^{\circ} \mathrm{C}$. The human peripheral blood samples were obtained from the blood bank at the Instituto Nacional de Enfermedades Respiratorias (INER) under approbation of the Institutional Ethical Review Board of INER.

The human MNs were cultured in RPMI 1640 medium (Cambrex, Walkersville, MD, USA) supplemented with $50 \mu \mathrm{g} / \mathrm{mL}$ gentamicin sulfate, $2.0 \mathrm{mmol} / \mathrm{L} \mathrm{L}$-glutamine, and $10 \%$ heat-inactivated pooled human serum at $37^{\circ} \mathrm{C}$ in a $5 \%$ $\mathrm{CO}_{2}$ atmosphere ( $\mathrm{MN}$ medium).

The human acute monocytic leukemia cell line, THP1, was purchased from the American Type Culture Collection (TIB202, ATCC, Rockville, MD, USA). THP-1 cells were grown in RPMI 1640 supplemented with 10\% fetal bovine serum (Lonza, Walkersville, MD, USA), $0.05 \mu \mathrm{M} \beta$ mercaptoethanol, $4 \mathrm{mM}$ L-glutamine, $100 \mathrm{U} / \mathrm{mL}$ penicillin, and $100 \mu \mathrm{g} / \mathrm{mL}$ streptomycin (THP medium). 
2.2. Effect of NDGA on Cell Viability. The MNs and THP1 cells were seeded at $3 \times 10^{5}$ cells/well in 48 -well plates in culture medium. The NDGA $(5-50 \mu \mathrm{M})$ was then added to the cells and incubated for $120 \mathrm{~h}$. After incubation, the cell viability was quantified by MTT reduction.

2.3. Effect of Iodoacetate or $\mathrm{H}_{2} \mathrm{O}_{2}$ on Cell Viability. The human MNs and THP- 1 cells $\left(3 \times 10^{5}\right.$ cells/well $)$ were cultured in 48 well plates. First, the cells were treated with $0-100 \mu \mathrm{M}$ IAA or 0-20 $\mathrm{mM} \mathrm{H}_{2} \mathrm{O}_{2}$ for $2 \mathrm{~h}$ to induce oxidative stress. Successively oxidants were replaced by fresh medium, and the incubation was continued until $24 \mathrm{~h}$. Cell viability was monitored by MTT reduction or trypan blue exclusion. In addition cell morphology was observed in bright field micrographs on $40 \mathrm{x}$ with phase contrast microscopy (Nikon Co.).

2.4. Protective Effect of NDGA on the Cytotoxicity-Induced by IAA or $\mathrm{H}_{2} \mathrm{O}_{2}$ in MN and THP-1 on Cell Viability. MNs and THP-1 cells $\left(3 \times 10^{5}\right.$ cells/well $)$ were cultured in 48 -well plates (MN or THP medium, resp.). The cells were pretreated with or without $20 \mu \mathrm{M}$ NDGA by $12 \mathrm{~h}$, and then cells were exposed to $(0-100 \mu \mathrm{M})$ IAA or $(0-20 \mathrm{mM}) \mathrm{H}_{2} \mathrm{O}_{2}$ for $2 \mathrm{~h}$ to induce oxidative stress and refreshed after removal of the toxic compounds. MTT reduction or trypan blue exclusion was determined $24 \mathrm{~h}$ after onset of IAA or $\mathrm{H}_{2} \mathrm{O}_{2}$ exposure.

2.5. Cell Viability Detection by MTT. Cell viability was determined using the 3-(4,5-dimethylthiazol-2-yl)-2,5diphenyltetrazolium bromide (MTT; Sigma, St. Louis, MO) reduction assay [31]. Briefly, MNs $\left(3 \times 10^{5}\right.$ cells/well) were seeded into 48-well plates; after the indicated treatments and time periods, $50 \mu \mathrm{L}$ MTT stock solution $(5.0 \mathrm{mg} / \mathrm{mL})$ was added to the cells and incubated for $2 \mathrm{~h}$ at $37^{\circ} \mathrm{C}$ in a $5 \% \mathrm{CO}_{2}$ atmosphere. The plates were then centrifuged at $1,500 \mathrm{~g}$ for $15 \mathrm{~min}$ at room temperature (RT), and the medium was carefully removed by aspiration. Subsequently, an acid isopropanol solution $(800 \mu \mathrm{L})$ was added to the wells, and the plates were shaken at $80 \mathrm{rpm}$ for $5 \mathrm{~min}$. Finally, the absorbance was measured at $570 \mathrm{~nm}$ in a microplate reader (Labsystems Multiskan). The number of viable cells was expressed as the index of MTT reduction. The control cells (without treatment) were assigned a maximum value of 1 , and the indices of the cells incubated with the different treatments were obtained with respect to the control cells.

2.6. Cytotoxicity Assay by Trypan Blue Exclusion. Cell viability also was monitored by trypan blue negative cells. Concisely, an aliquot on the cell suspension was diluted $1: 1$ $(\mathrm{v} / \mathrm{v})$ with $0.4 \%$ trypan blue, and the cells were counted with a hemocytometer [32]. The results represent the percentage with respect to control of trypan blue negative cells (without treatment). This assay was done three times for independent experiments.

\subsection{Determination of Reactive Oxygen Species (ROS) Production by Flow Cytometry}

2.7.1. IAA Treatment. MNs $\left(5 \times 10^{5}\right.$ cells/well $)$ were cultured in 24-well plates. First, the cells were pretreated with or without $20 \mu \mathrm{M}$ NDGA for $12 \mathrm{~h}$ and immediately exposed to nonlethal concentration of IAA $(2.5,5.0$ and $7.5 \mu \mathrm{M})$ by $48 \mathrm{~h}$. Then, ROS production was determined.

2.7.2. $\mathrm{H}_{2} \mathrm{O}_{2}$ Treatment. MNs $\left(5 \times 10^{5}\right.$ cells/well $)$ were pretreated with or without $20 \mu \mathrm{M}$ NDGA for $12 \mathrm{~h}$ and then exposed to $\mathrm{H}_{2} \mathrm{O}_{2}(0.5,1.0$ and $2.0 \mathrm{mM})$ by $12 \mathrm{~h}$. Then, ROS production was determined.

ROS detection was measured with the fluorescent marker 5-(and-6)-carboxy-2 $2^{\prime}, 7^{\prime}$-dichlorodihydrofluorescein diacetate (carboxy-DCFDA; Invitrogen, Carlsbad, CA), which is an acetylated form of fluorescein, and was used as an ROS indicator [33].

After treatments, the MNs were washed twice with phosphate-buffered saline solution (PBS) and immediately loaded with $10 \mu \mathrm{M}$ carboxy- $\mathrm{H}_{2} \mathrm{DCFDA}$ for $30 \mathrm{~min}$ at $37^{\circ} \mathrm{C}$ in the dark for ROS production. Following this incubation, the cells were centrifuged at $600 \mathrm{~g}$ for $5 \mathrm{~min}$. The cells were washed twice with PBS and then fixed with $1 \%$ paraformaldehyde and stored at $4^{\circ} \mathrm{C}$ until acquisition with a FACSCalibur flow cytometer (BD, San Jose, CA, USA). The number of events acquired was 10,000.

\subsection{Determination of CD33 Expression by Flow Cytometry}

2.8.1. IAA Treatment. MNs $\left(5 \times 10^{5}\right.$ cells/well $)$ were cultured in 24-well plates. First, the cells were pretreated with or without $20 \mu \mathrm{M}$ NDGA for $12 \mathrm{~h}$ and immediately exposed to no lethal concentration of IAA $(2.5,5.0$ and $7.5 \mu \mathrm{M})$ by $72 \mathrm{~h}$. Then, CD33 expression was determined.

2.8.2. $\mathrm{H}_{2} \mathrm{O}_{2}$ Treatment. MNs $\left(5 \times 10^{5}\right.$ cells/well $)$ were pretreated with vehicle or $20 \mu \mathrm{M}$ NDGA for $12 \mathrm{~h}$ and then, exposed to $\mathrm{H}_{2} \mathrm{O}_{2}(0.5,1.0$ and $2.0 \mathrm{mM})$ by $24 \mathrm{~h}$. Then, CD33 expression was determined.

To measure CD33 in cell surface of MNs, the cells were washed with PBS and immediately loaded with saturating amounts of phycoerythrin- (PE-) labeled mAbs against CD33 and incubated for $15 \mathrm{~min}$ at RT in the dark. The cells were fixed with $1 \%$ paraformaldehyde and stored at $4^{\circ} \mathrm{C}$ until acquisition. The number of events acquired was 10,000.

The results of ROS level and CD33 expression were analyzed with CellQuest software (BD Biosciences) and were expressed as the index of the mean fluorescence intensity (MFI) compared to the control without treatment.

2.9. Glutathione/Glutathione Disulfide Ratio Detection. THP1 cells $\left(3 \times 10^{6}\right.$ cells/well) were cultured in 6 -well plates. First, the cells were pretreated with vehicle or $20 \mu \mathrm{M}$ NDGA for $12 \mathrm{~h}$ and immediately exposed to IAA $(2.5,5.0$ and $7.5 \mu \mathrm{M})$ or $\mathrm{H}_{2} \mathrm{O}_{2}(0.5,1.0$ and $2.0 \mathrm{mM})$ by additional $24 \mathrm{~h}$. Then, glutathione was measured.

GSH and GSSG levels were measured in cell extracts using the GSH reductase enzyme method [34]. This assay is based on the reaction of GSH with $5,5^{\prime}$-dithio-bis (2 nitrobenzoic acid) (DNTB) to form 5-thio-2-nitrobenzoic acid (TNB), detectable at $\lambda=412 \mathrm{~nm}$. The test is specific to GSH on the basis of the specificity of the GSH reductase enzyme to GSH: the rate of accumulation of TNB is proportional 
to the concentration of GSH in the sample. For this assay, the cells extract was diluted 1:1 with KPE buffer prior to addition of freshly prepared DTNB and GSH reductase solutions. Following addition of $\beta$-NADPH, the absorbance was measured immediately and at $30 \mathrm{~s}$ intervals for $1.5 \mathrm{~min}$. The rate of change in absorbance was compared to that of GSH standards. The measurement of GSSG in each sample was identical to that used for the measurement of GSH, but with a previous treatment of each sample with 2-VP, which reacts out with GSH.

2.10. Statistics. The data were analyzed with Prism 5 software (GraphPad, San Diego, CA) using a two-way analysis of variance (ANOVA) followed by the Bonferroni multiple comparison test or with a one-way ANOVA followed by the Dunnett's test, as appropriate. A value of $P<0.05$ was considered significant.

\section{Results}

3.1. Effect of NDGA, IAA and $\mathrm{H}_{2} \mathrm{O}_{2}$ in Human Monocytes on Cell Viability. First, we evaluated the effect of NDGA on cell viability and determined that NDGA did not decrease the cell viability of MNs at concentrations ranging from 5 to $30 \mu \mathrm{M}$ (Figure 1(a)); however, the viability of THP-1 cells was slightly decreased at NDGA concentrations of 25 and $30 \mu \mathrm{M}$ after $120 \mathrm{~h}$ incubation. Therefore, the concentration of $20 \mu \mathrm{M}$ was chosen to evaluate the potential antioxidant effect of NDGA against the damage induced by IAA and $\mathrm{H}_{2} \mathrm{O}_{2}$ on MNs and THP-1 cells.

We also evaluated the effects of different concentrations of IAA and $\mathrm{H}_{2} \mathrm{O}_{2}$ on cell viability. The cells were incubated with these oxidants just by $2 \mathrm{~h}$; then the compounds were removed and fresh medium with $20 \mu \mathrm{M}$ NDGA was added. The cells were incubated until $24 \mathrm{~h}$ and viability quantified. As expected, IAA caused a dose-dependent decrease in the viability of the MNs and THP-1 cells. The MN viability decreased progressively and was significant at a concentration of $10 \mu \mathrm{M}$ IAA. The THP-1 cell viability decreased significantly at 50 to $100 \mu \mathrm{M}$ (Figure $1(\mathrm{~b})$ ). At the same way, $\mathrm{H}_{2} \mathrm{O}_{2}(2.5-$ $20 \mathrm{mM}$ ) caused cell death in a concentration-dependent manner. $\mathrm{MN}$ cell death increased progressively from 5.0 to $20 \mathrm{mM} \mathrm{H}_{2} \mathrm{O}_{2}$. THP-1 cell death was substantial and increased significantly from 2.5 to $20 \mathrm{mM} \mathrm{H}_{2} \mathrm{O}_{2}$ (Figure 1 (c)).

We also verified THP-1 cell morphology in bright field micrographs. These cells were round and bright throughout the field when treated with vehicle or $20 \mu \mathrm{M}$ NDGA (Figure 3). Nevertheless, IAA $(25-100 \mu \mathrm{M})$ and $\mathrm{H}_{2} \mathrm{O}_{2}$ (5$20 \mathrm{mM}$ ) induced morphological alterations, such as loss of shape round. Both oxidants were able to generate damage on the cells which were dependent on concentrations (Figures 3(a) and 3(b) left side).

We then assessed the protective effect of NDGA on MNs and THP-1 cells cultured in the presence of IAA and $\mathrm{H}_{2} \mathrm{O}_{2}$ (Figure 2). Our results demonstrate that cell death was decreased in the MNs at all concentrations of IAA (Figure 2(a)), and the NDGA avoided the death of the THP- 1 cells by $31 \%$ and $41 \%$ at $50 \mu \mathrm{M}$ and $100 \mu \mathrm{M}$ IAA, respectively (Figure $2(\mathrm{c})$ ). In addition, pretreatment with
NDGA decreased cell damage by $\mathrm{H}_{2} \mathrm{O}_{2}$, and cell death was significantly diminished over a range of $5-20 \mathrm{mM} \mathrm{H}_{2} \mathrm{O}_{2}$ (Figure 2(b)). For the THP-1 cells, the protective effect of NDGA was significant at $10 \mathrm{mM} \mathrm{H}_{2} \mathrm{O}_{2}$ (Figure 2(d)). These results also were comparable with percentages of trypan blue negative cells (Figures 2(e) and 2(f)).

Likewise these results were corroborated observing cell morphology in bright field micrographs (Figure 3). Cells incubated with $20 \mu \mathrm{M}$ NDGA diminished significantly damage in cell morphology when cells were treated with IAA (25 and $50 \mu \mathrm{M}$ ) or $\mathrm{H}_{2} \mathrm{O}_{2}$ (5 and $10 \mathrm{mM}$ ). But the cells pretreated with NDGA and highest concentration of IAA $(100 \mu \mathrm{M})$ or $\mathrm{H}_{2} \mathrm{O}_{2}$ (15 and $20 \mathrm{mM}$ ) still showed cell damage (Figures 3(a) and 3 (b) and right side).

3.2. Determination of ROS Production Induced by IAA and $\mathrm{H}_{2} \mathrm{O}_{2}$ in Human Monocytes. In this study, we showed that low IAA concentration caused a significant increase of ROS during at $48 \mathrm{~h}$ incubation (Figures 4 (a) and $4(\mathrm{c})$ ). The relative ROS production was increased for all of the IAA concentrations tested ( 2.5 to $7.5 \mu \mathrm{M})$. Similarly, $\mathrm{H}_{2} \mathrm{O}_{2}$ induced a significant increase in ROS production (Figures $4(\mathrm{~b})$ and $4(\mathrm{~d})$ ) at concentrations of 1.0 and $2.0 \mathrm{mM}$ after at $12 \mathrm{~h}$ incubation.

3.3. Glutathione Level in THP-1 Cells Induced by NDGA, $I A A$, and $\mathrm{H}_{2} \mathrm{O}_{2}$. The effect of NDGA and toxic compounds (IAA or $\mathrm{H}_{2} \mathrm{O}_{2}$ ) on GSH levels was monitored by redox status in THP-1 cells (Figure 5). First, It was found that IAA or $\mathrm{H}_{2} \mathrm{O}_{2}$ induced reduction of [GSH] + [GSSG] and [GSH] concentrations in a concentration-dependent manner (Figures 5(a) and 5(b)) suggesting that both toxics caused an oxidative stress to the cells. In contrast, pretreatment of cells with $20 \mu \mathrm{M}$ NDGA $(5 \mu \mathrm{M}$ IAA/NDGA or $1 \mathrm{mM}$ $\mathrm{H}_{2} \mathrm{O}_{2}$ /NDGA) abrogated the reduction of [GSH] + [GSSG] and $[\mathrm{GSH}]$ concentrations induced by oxidants. In addition, we also observed that NDGA alone caused slight increase of $[\mathrm{GSH}]+[\mathrm{GSSG}]$ and $[\mathrm{GSH}]$ levels (Figures 5(c) and 5(d)).

3.4. CD33 Expression by IAA and $\mathrm{H}_{2} \mathrm{O}_{2}$ in Human Monocytes. We showed that treatment with either IAA or $\mathrm{H}_{2} \mathrm{O}_{2}$ significantly decreased CD33 expression levels in MNs. In IAA-treated cells $(2.5,5.0$, and $7.5 \mu \mathrm{M})$, CD33 expression levels decreased significantly compared to the control; this decrease in CD33 expression on the cell surface occurred in a concentration-dependent manner (Figures 6(a) and 6(c)). In MNs incubated with 1 and $2 \mathrm{mM} \mathrm{H}_{2} \mathrm{O}_{2}$, a significant reduction in CD33 expression was observed (Figures 6(b) and $6(d))$.

3.5. NDGA Effect on ROS Production and CD33 Expression in Human Monocytes. The protective effect of NDGA was evaluated with regard to $\mathrm{H}_{2} \mathrm{O}_{2}$ - or IAA-induced ROS production and CD33 expression in MNs (Figure 7). NDGA was added to the culture prior to the oxidant exposure $(5 \mu \mathrm{M}$ IAA and $1 \mathrm{mM} \mathrm{H}_{2} \mathrm{O}_{2}$ ), and it was maintained in the culture medium during the incubation. The ROS and CD33 expression levels were then measured by flow cytometry.

NDGA prevented oxidative stress because the MNs cultured with NDGA/IAA (Figure $7(\mathrm{a})$ ) or $\mathrm{NDGA} / \mathrm{H}_{2} \mathrm{O}_{2}$ 


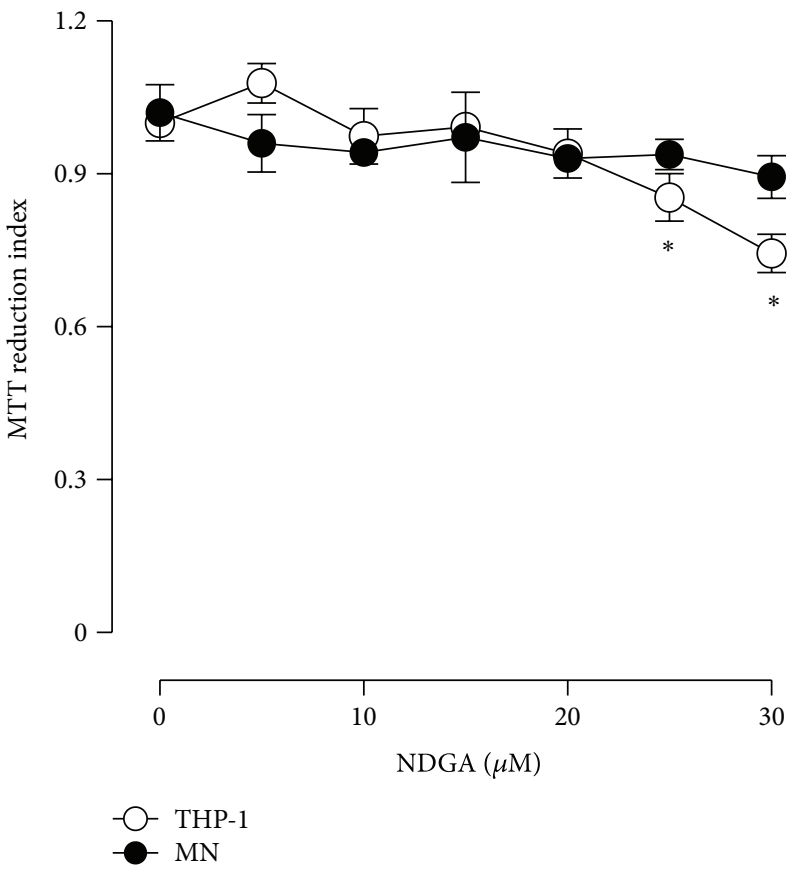

(a)

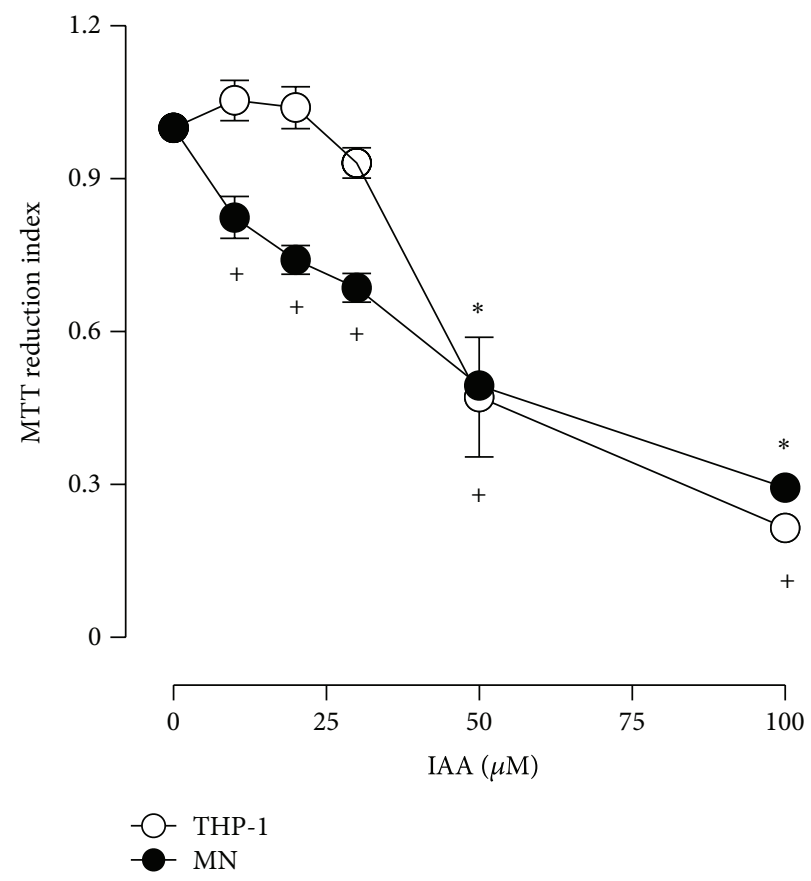

(b)

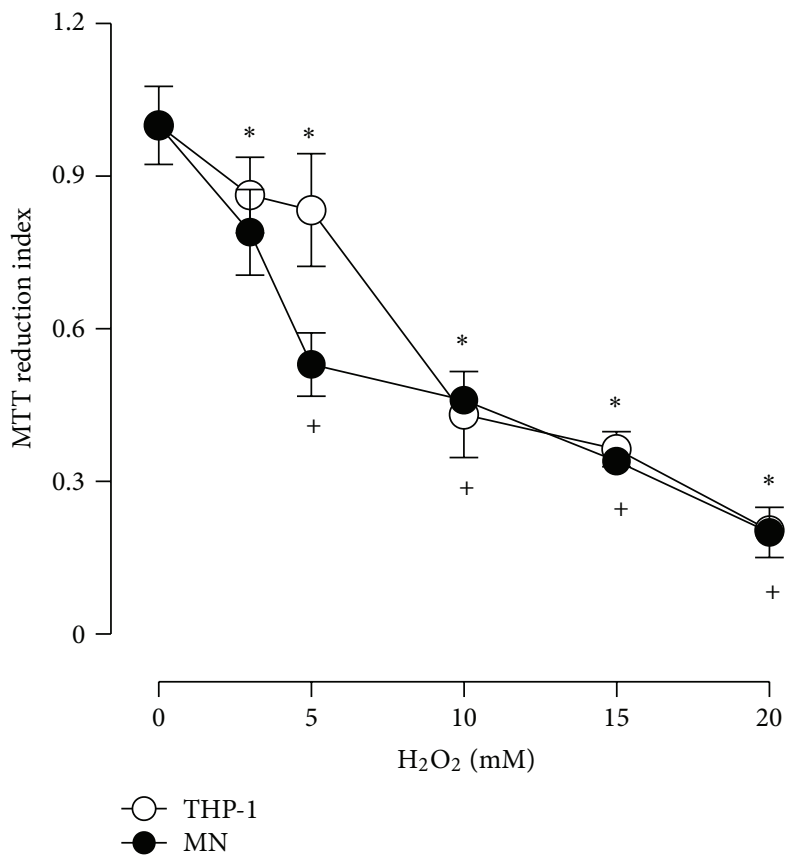

(c)

Figure 1: Effect of (a) NDGA, (b) IAA, and (c) $\mathrm{H}_{2} \mathrm{O}_{2}$ on the viability of human MN and THP-1 cells. (a) NDGA (0-30 $\mu$ M) was added for $120 \mathrm{~h}$ before the measurement of viability. In addition, cells were exposed to (b) IAA $(0-100 \mu \mathrm{M})$ or (c) $\mathrm{H}_{2} \mathrm{O}_{2}(0-20 \mathrm{mM})$ for $2 \mathrm{~h}$. At the end of the exposition time, the media containing IAA and $\mathrm{H}_{2} \mathrm{O}_{2}$ were replaced with fresh medium. Viability was assessed at the end of $24 \mathrm{~h}$ of incubation. The number of viable cells is expressed as index of MTT reduction. Data are expressed as mean $\pm \mathrm{SEM} ; n=5$. ${ }^{*} P<0.05$ versus $\mathrm{MN}$ (without treatment) and ${ }^{+} P<0.05$ versus THP-1 (without treatment). MN: human monocytes; THP1: human acute monocytic leukemia cell line. 


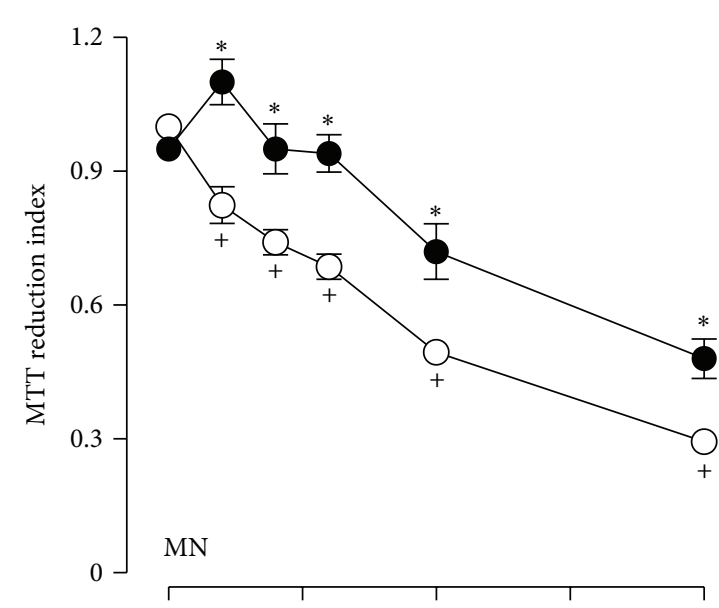

(a)

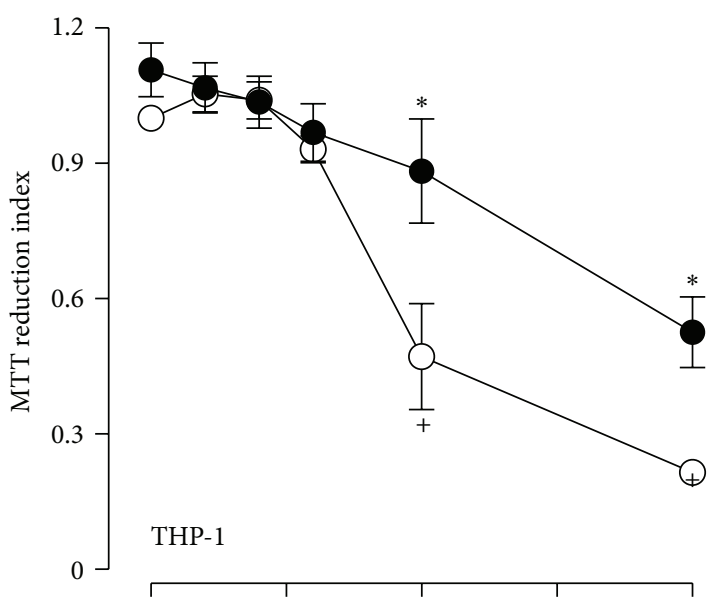

(c)

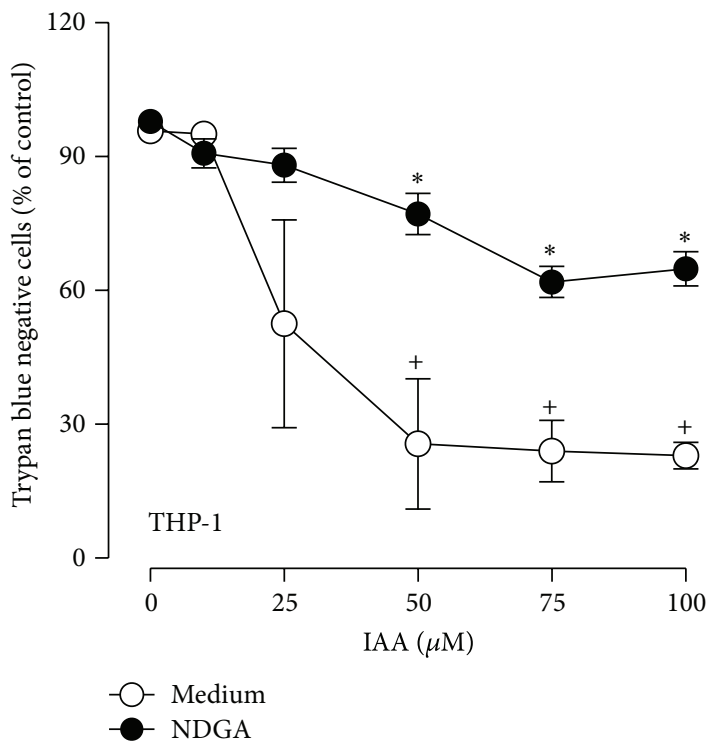

(e)

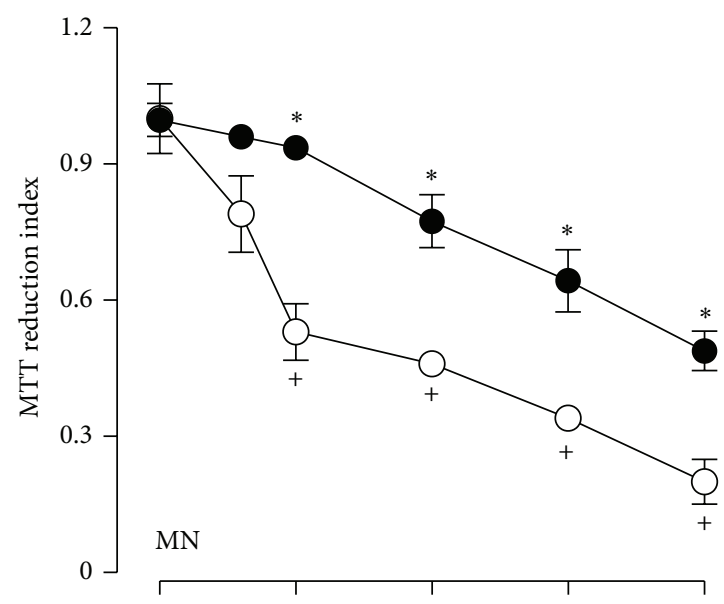

(b)

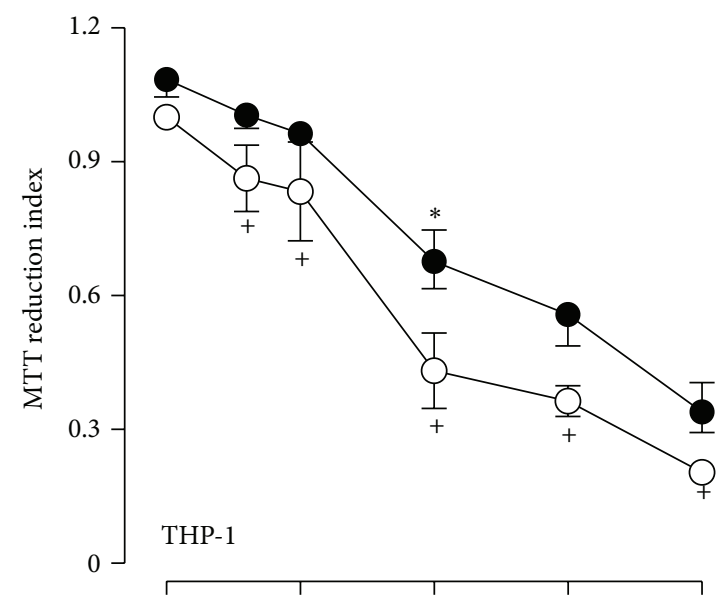

(d)

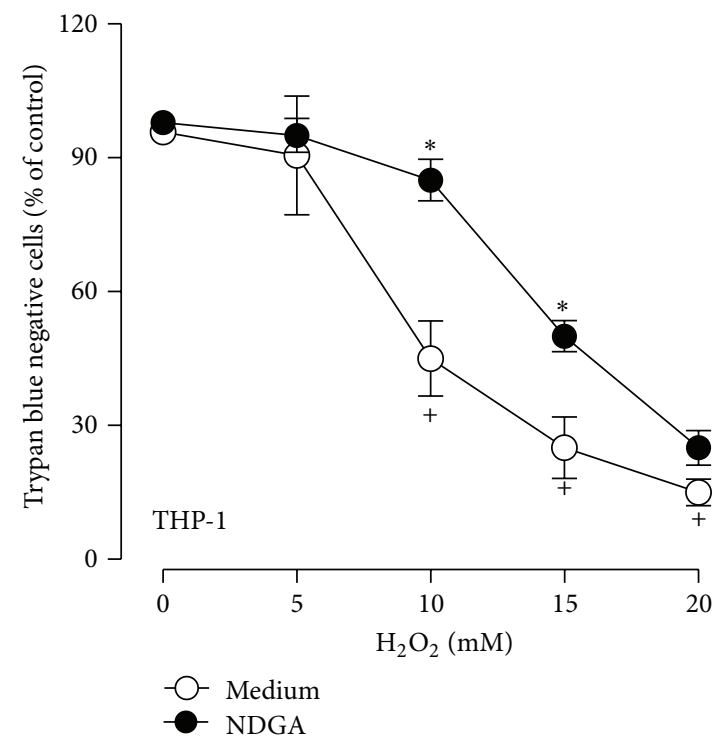

(f)

Figure 2: Protective effect of NDGA on the cytotoxicity-induced by ((a), (c), and (e)) IAA and ((b), (d), and (f)) $\mathrm{H}_{2} \mathrm{O}_{2}$ in human cells. ((a), (b)) MN and ((c), (d), (e), (f)) THP-1 cells were pretreated in absence or presence of $20 \mu \mathrm{M}$ NDGA by $12 \mathrm{~h}$. Cell cultures were exposed to IAA or $\mathrm{H}_{2} \mathrm{O}_{2}$ for $2 \mathrm{~h}$ and refreshed after removal of the toxic compounds. MTT reduction or trypan blue exclusion was determined $24 \mathrm{~h}$ after the onset of IAA or $\mathrm{H}_{2} \mathrm{O}_{2}$ exposure. The number of viable cells is expressed as ((a), (b), (c), (d)) index of MTT reduction or ((e), (f)) percentage of trypan blue negative cells. Data are expressed as mean \pm SEM; $n=5 .{ }^{+} P<0.05$ versus control (without IAA or $\mathrm{H}_{2} \mathrm{O}_{2}$ ) and ${ }^{*} P<0.05$ versus control (without NDGA). 


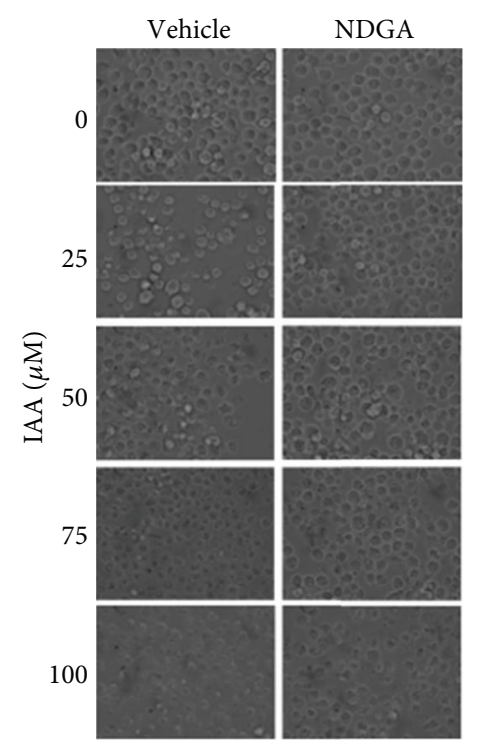

(a)

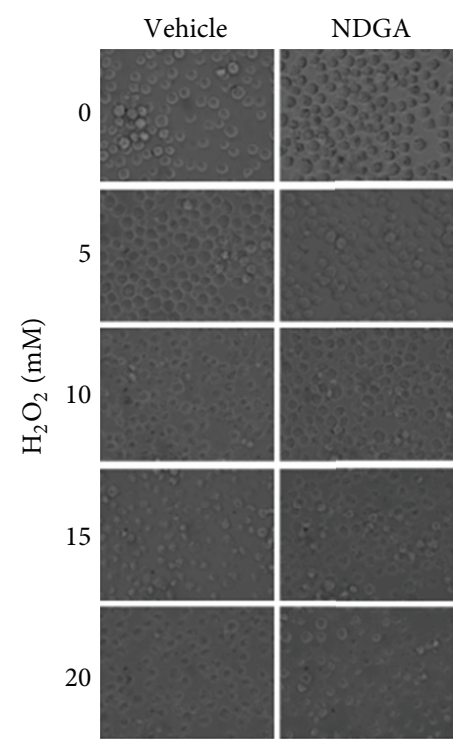

(b)

FIGURE 3: Representative phase contrast micrographs showing the effect of NDGA on the damage induced by different concentrations of (a) IAA or (b) $\mathrm{H}_{2} \mathrm{O}_{2}$ in THP-1 cells. Cells were treated with vehicle (left side) or $20 \mu \mathrm{M}$ NDGA (right side) by 12 h; after this the cells were exposed to IAA or $\mathrm{H}_{2} \mathrm{O}_{2}$ for $2 \mathrm{~h}$. After this time these compounds were withdrawn and fresh medium with NDGA was added. Representative images were obtained $24 \mathrm{~h}$ after the onset of IAA or $\mathrm{H}_{2} \mathrm{O}_{2}$ exposure.

(Figure 7(b)) showed less ROS production. In addition, the decrease of CD33 expression was attenuated by NDGA in the cells exposed to IAA (Figure 7(c)) and $\mathrm{H}_{2} \mathrm{O}_{2}$ (Figure $7(\mathrm{~d})$ ). Notably, the cells exposed to NDGA had a similar CD33 protein expression level compared to the untreated control cells.

\section{Discussion}

It is well established that NDGA has biological properties, such as anticarcinogenic [35-38], antidiabetic, antiviral, antioxidant, and anti-inflammatory activities in human cell cultures and animal models $[3,39]$. Furthermore, NDGA has beneficial health properties, including the growth inhibition of human cancers in vivo [40,41], the degradation of preformed Alzheimer's beta-amyloid fibrils in vitro [42], and the protection of cultured rat hippocampal neurons against the toxicity of the amyloid beta-peptide [43].

The purpose of this study was to evaluate the potential protective effects of NDGA on human MNs cultured under oxidative stress conditions. MNs are an essential host defense against microorganisms. MNs use mechanisms that consist of ingesting bacterial material through phagocytosis and killing infectious agents by producing ROS to protect the host [44]. Furthermore, ROS production performs other important physiological functions. For example, ROS participate in signal transduction and gene expression $[45,46]$. MNs maintain intracellular redox homeostasis by balancing the production of ROS with their removal through cellular antioxidant defense systems.

However, excessive ROS production can be lethal for the MNs because ROS can attack biomolecules, which causes changes in the structure and function of these molecules.
MNs are well known to play a crucial role in the development of ROS-induced pathologies because they can produce nonnegligible amounts of ROS. Because of the negative long-term side effects of ROS production by monocytes, modulating ROS generation and maintaining the redox state of the cell at the required physiological level are considered a main therapeutic target $[25,47]$. NDGA has a protective effect due to its antioxidant capacity and has garnered increasing interest because it has been reported to contribute to the prevention or delay of oxidative stress-induced damage [4]. In this study, NDGA toxicity was first evaluated in human MNs. Our results demonstrated that, at concentrations of NDGA ranging from 5 to $25 \mu \mathrm{M}$, NDGA is not cytotoxic to either THP-1 cells or human MNs over $120 \mathrm{~h}$ of treatment. This finding was comparable to animal cells, indicating that NDGA is nontoxic at low doses $[4,9,10]$.

The potential protective effect of NDGA was then evaluated in two toxicity models using IAA and $\mathrm{H}_{2} \mathrm{O}_{2}$ to induce toxicity. Under these conditions, the oxidants caused cell death in a concentration-dependent manner in the THP-1 cells and human MNs. It was previously reported that these oxidants caused damage in primary cultures of rat neurons $[9,10]$.

IAA injury has been related to ROS production in primary cultures of rat neurons $[8,19]$. It also has been demonstrated that in cultured hippocampal neurons, IAA reduces ATP levels and cell survival [18]. Our results suggest that IAA toxicity is related to the exacerbated ROS production and subsequent cell death of MNs (Figures 1(b) and 3(a)).

In contrast, $\mathrm{H}_{2} \mathrm{O}_{2}$ is a source of ${ }^{\circ} \mathrm{OH}$ in the presence of transition metal ions. This oxygen metabolite reacts rapidly 


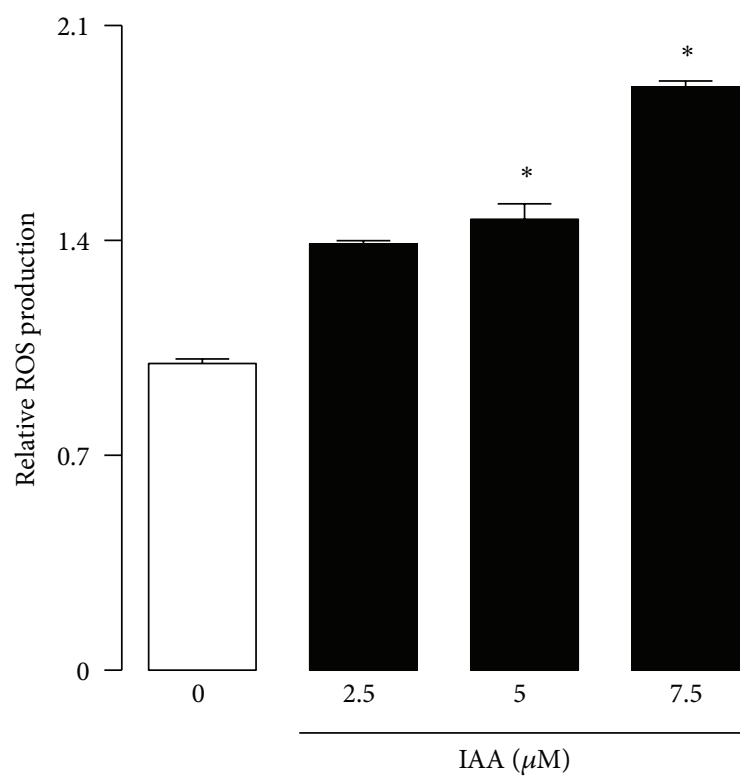

(a)

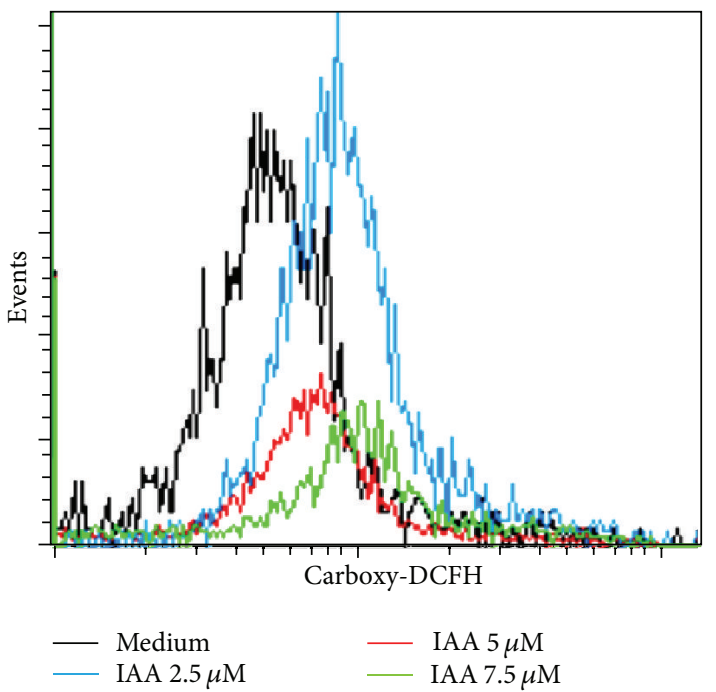

(c)

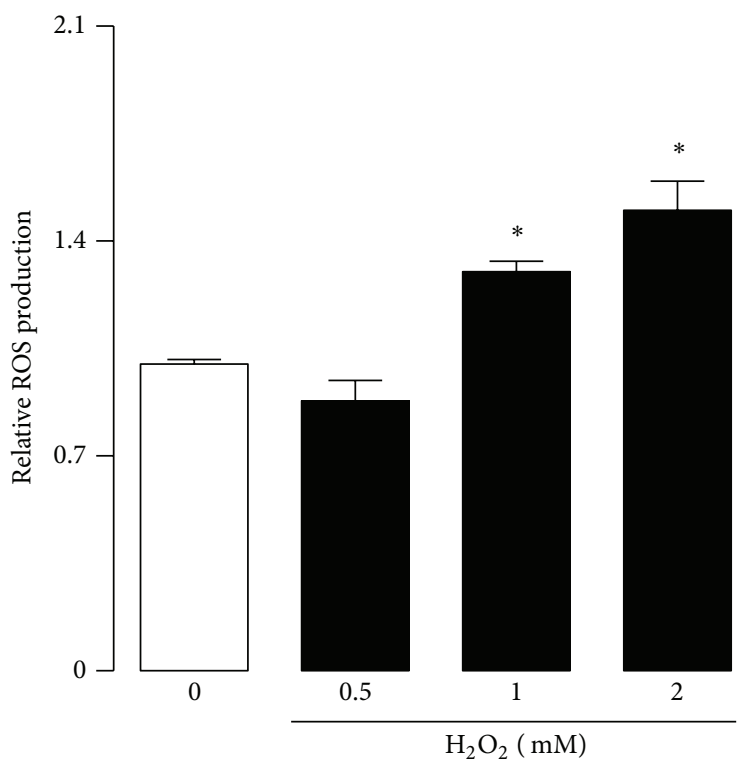

(b)

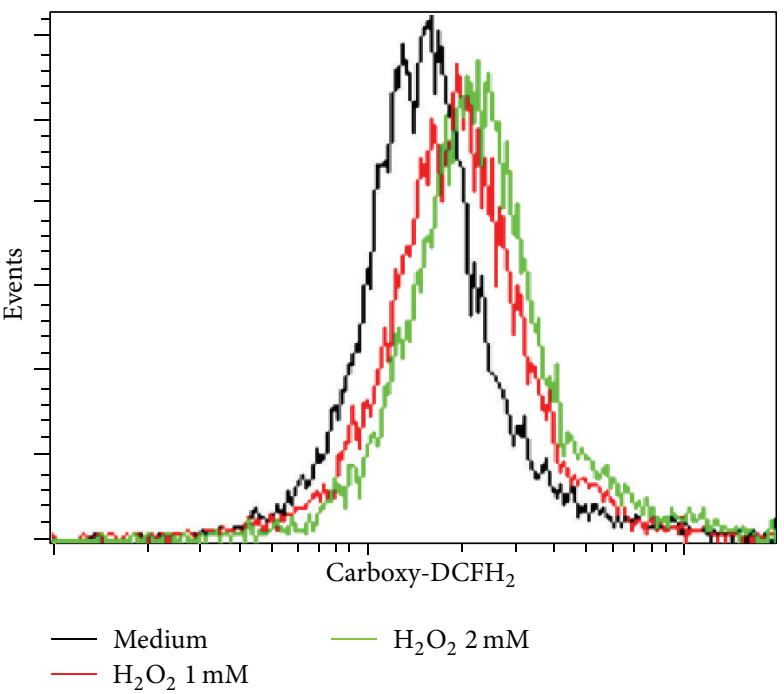

(d)

Figure 4: Effect of ((a), (c)) IAA or ((b), (d)) $\mathrm{H}_{2} \mathrm{O}_{2}$ on ROS generation in MN. Cells were treated 48 h with IAA by 12 with $\mathrm{H}_{2} \mathrm{O}_{2}$. Then, ROS production was determined by flow cytometry. ROS level was expressed as index with respect to control without treatment. Data are expressed as mean \pm SEM; $n=5 .{ }^{*} P<0.05$ versus control (without IAA or $\mathrm{H}_{2} \mathrm{O}_{2}$ ).

and broadly with all biomolecules. As expected, $\mathrm{H}_{2} \mathrm{O}_{2}$ caused increased ROS production and cell death [12]. In addition, it was recently described that $\mathrm{H}_{2} \mathrm{O}_{2}$ promotes the opening of the mitochondrial permeability transition pore (PTP), resulting in membrane depolarization, uncoupling of oxidative phosphorylation, and potential cell death in porcine LLC-PK1 cells [11].

In addition, we demonstrated that NDGA protected MNs and THP-1 cells against $\mathrm{H}_{2} \mathrm{O}_{2}$. We observed that treatment with NDGA prior to the toxic challenges induced by IAA and $\mathrm{H}_{2} \mathrm{O}_{2}$ significantly diminished the toxicities of these compounds. In this context, it has been shown that the protective effect of NDGA is predominantly due to its antioxidant capacity. In fact, the direct ROS scavenging capacity and induction of antioxidant enzymes via the Nrf2 pathway may be involved in the mechanism by which NDGA exerts its protective effect $[4,9-11]$. Recently, it was described that NDGA can prevent the mitochondrial damage that is induced by oxidative stress in renal epithelial LLC-PK1 cell cultures [11] and in an animal model of renal damage [48].

We also explored the effect of NDGA on the oxidant stress-induced downregulation of CD33 expression in human MNs. Our results indicated that NDGA is a potent antioxidant that can prevent low levels of oxidative stress and can 


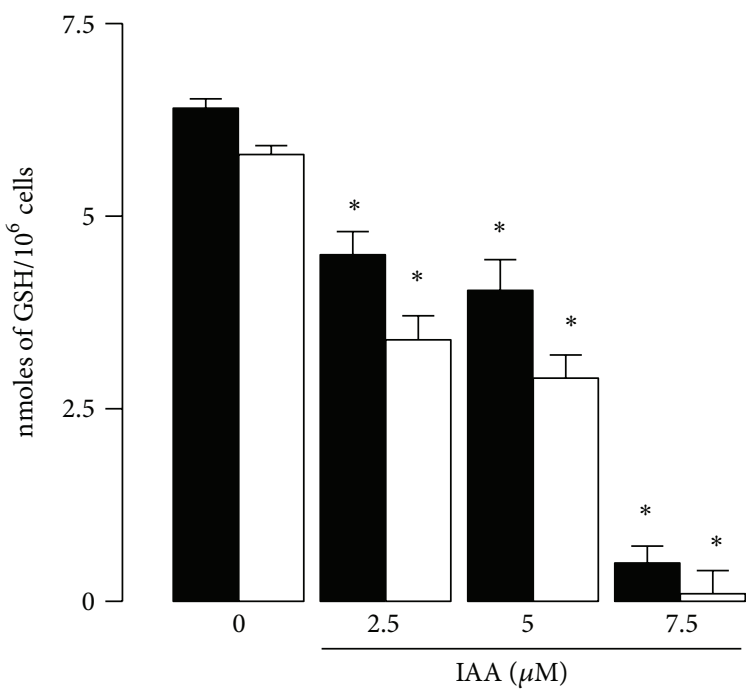

(a)

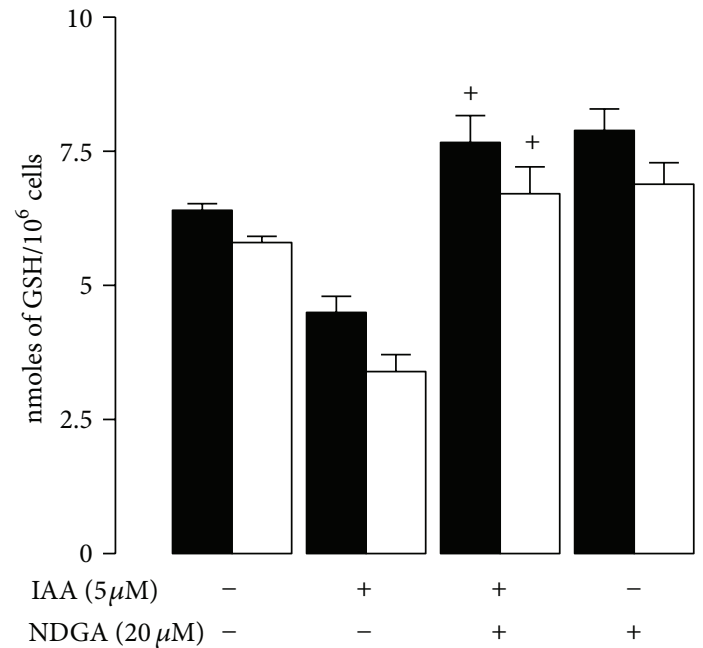

(c)

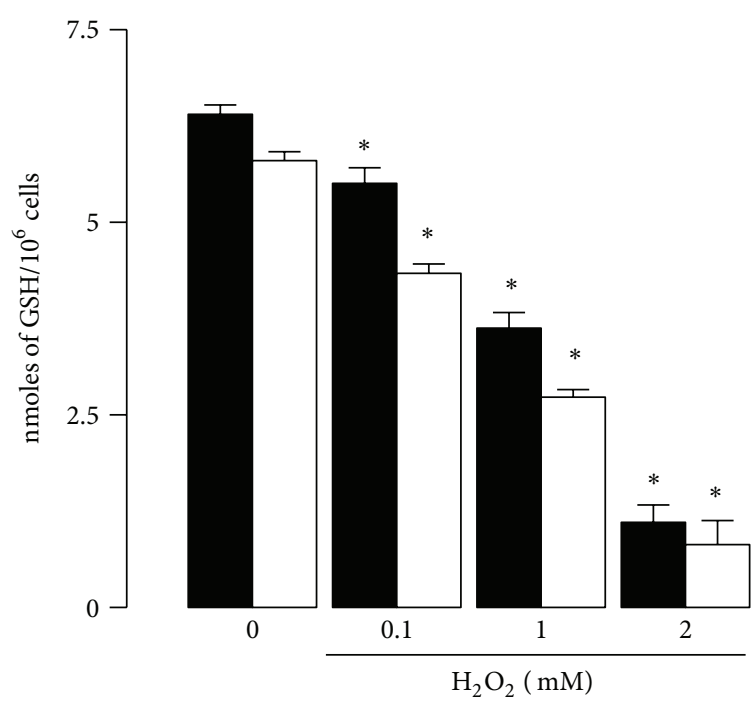

(b)

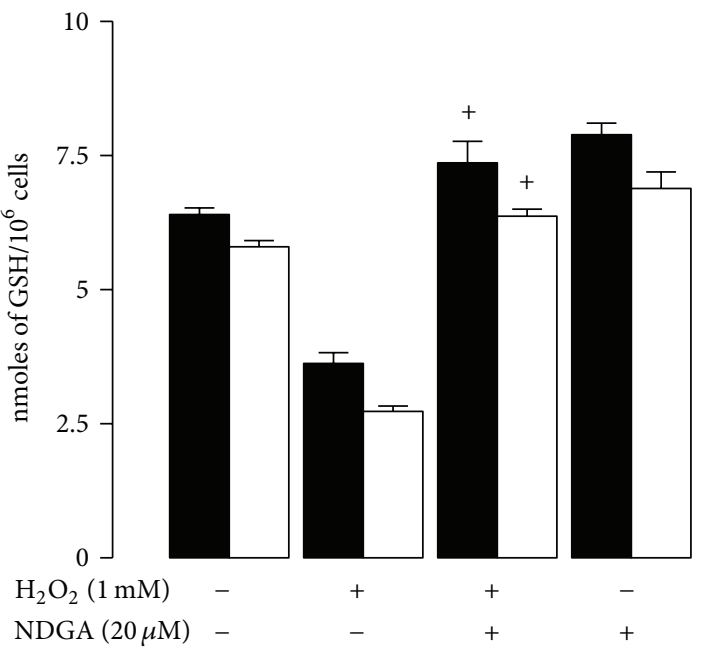

(d)

Figure 5: Effect of IAA or $\mathrm{H}_{2} \mathrm{O}_{2}$ on GSH + GSSG and GSH levels in THP-1 cells. Cells were treated $24 \mathrm{~h}$ with (a) IAA or (b) $\mathrm{H}_{2} \mathrm{O}_{2}$. After this time these compounds were withdrawn and fresh medium was added. GSSG and GSH levels were measured $24 \mathrm{~h}$ after the addition of toxic compounds. In addition the effect of NDGA on GSSG+GSH and GSH levels in (c) IAA or (d) $\mathrm{H}_{2} \mathrm{O}_{2}$ treated cells was also studied. Cells were treated with vehicle or $20 \mu \mathrm{M}$ NDGA by $12 \mathrm{~h}$; after this the cells were exposed to $5 \mu \mathrm{M}$ IAA or $1 \mathrm{mM} \mathrm{H}_{2} \mathrm{O}_{2}$ for $24 \mathrm{~h}$. GSSG and GSH levels were measured $24 \mathrm{~h}$ after the addition of toxic compounds. GSH levels were quantified by spectrophotometric/microplate reader assay. Data are expressed as mean \pm SEM; $n=3 .{ }^{*} P<0.05$ versus control (without IAA or $\mathrm{H}_{2} \mathrm{O}_{2}$ ) and ${ }^{+} P<0.05$ versus the respective toxic compound.

also prevent the decrease in CD33 expression in cells treated with IAA and $\mathrm{H}_{2} \mathrm{O}_{2}$.

The mechanisms involved in the expression of CD33 have not been fully elucidated. But have been described two mechanisms of repressive control $[49,50]$. First, CD33 activity is decreased by SOCS3, which is a member of the suppressor of cytokine signaling (SOCS) protein family. The binding of SOCS3 to the phosphorylated immunoreceptor tyrosine-based inhibitory motifs (ITIM) of CD33 induces the proteosomal degradation of both molecules and the reduction of $\mathrm{CD} 33$ expression on surface monocytes and blockades the increased secretion of IL-1 $\beta$, IL- 8 , and TNF$\alpha[49,51]$. The second mechanism described in myeloma cells was induced by IL- 6 . This cytokine upregulates the expression of helix-loop-helix leucine zipper transcription factor (MYC) via transcriptional regulator of the immune response 3 (STAT3) phosphorylation. MYC binds directly to the promoter region of the CCAAT enhancer binding protein $\alpha$ (C/EBPA gene), which downregulates C/EBPA and thus CD33 gene expression is decreased [50]. Finally, Gonzalez et al. (2012) showed that hyperglycemia diminished both mRNA and CD33 expression in surface cell. But, when the human monocytes were treated with $\alpha$-tocopherol, this negative modulation was prevented. In fact, it is well known that SOCS3 is modulated by oxidative stress in response to hyperglycemia $[52,53]$ and the TNF- $\alpha$ production is 


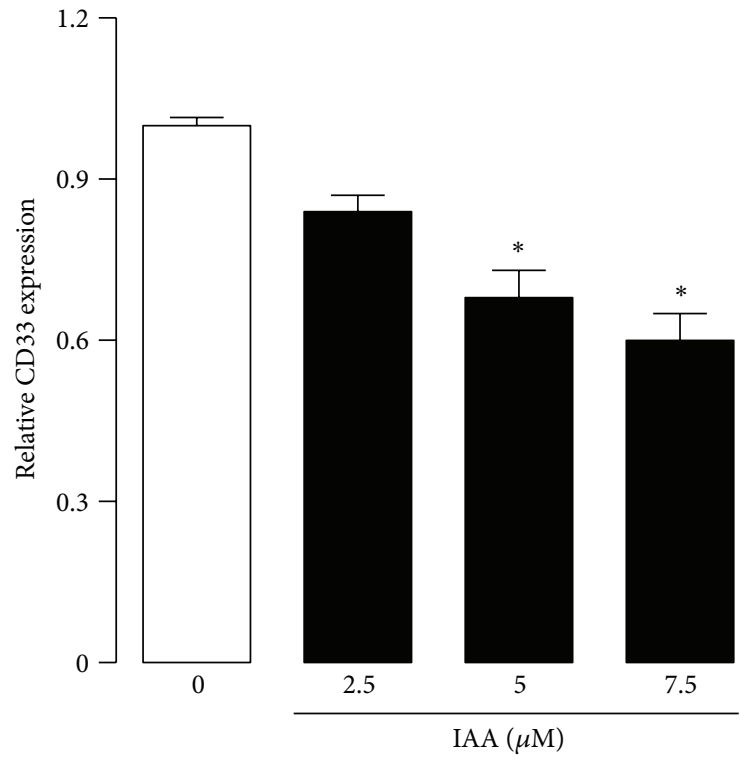

(a)

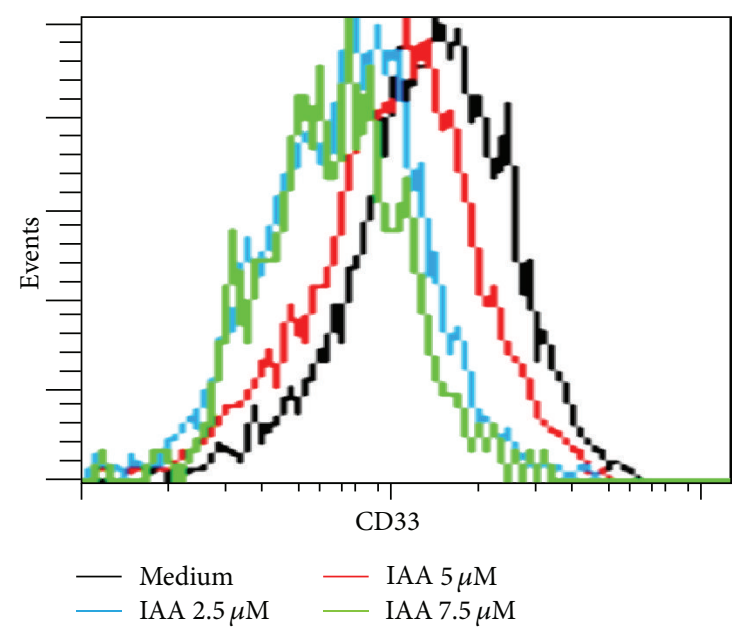

(c)

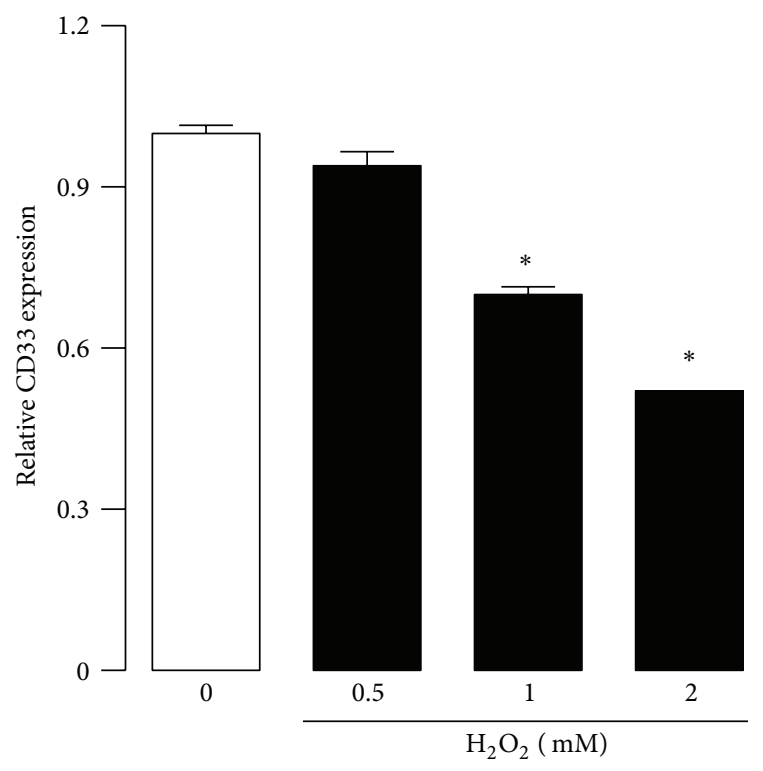

(b)

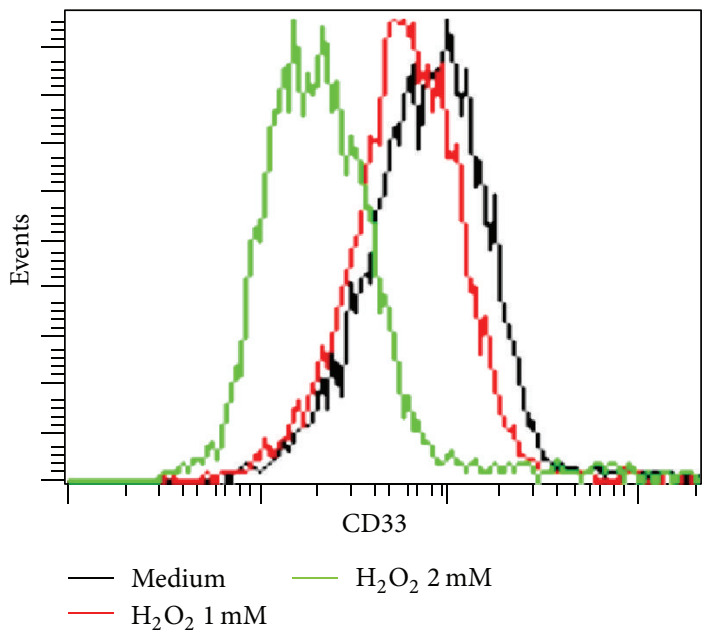

(d)

Figure 6: Effect of ((a), (c)) IAA or ((b), (d)) $\mathrm{H}_{2} \mathrm{O}_{2}$ on CD33 expression in MN. Cells were treated by $72 \mathrm{~h}$ with IAA or by $48 \mathrm{~h}$ with $\mathrm{H}_{2} \mathrm{O}_{2}$. Then, CD33 protein presence was determined by flow cytometry. The protein level was expressed as index with respect to control without treatment. Data are expressed as mean $\pm \mathrm{SEM} ; n=5$. ${ }^{*} \mathrm{P}<0.05$ versus control (without IAA or $\mathrm{H}_{2} \mathrm{O}_{2}$ ).

induced by $\mathrm{H}_{2} \mathrm{O}_{2}$ via oxidative stress-related signal pathways [54]. Because our previous study found that the antioxidant $\alpha$-tocopherol prevents TNF- $\alpha$ production and CD33 downregulation, therefore it is possible that ROS induction could be participating in these processes.

Furthermore, MYC is induced by oxidative stress generated by sodium arsenate in the cell line MCG-7 [55]. Even C/EBPA is susceptible to negative regulation by oxidative stress induced by $\mathrm{H}_{2} \mathrm{O}_{2}$ in 3T3-L preadipocyte cells [56] and by ethanol in HepG2 cells [57]. In addition, we observed a significant decrease of $\mathrm{CD} 33$ protein in surface cells in oxidative condition induced by IAA and $\mathrm{H}_{2} \mathrm{O}_{2}$. This result supports the idea that oxidative stress could alter the transcription of CD33 by modulating the transcription factors such as STAT, MYC, and C/EBPA.
Preliminary studies in our research group demonstrated that oxidative stress induced by hyperglycemia decreases CD33 expression in human monocytes, but the pretreatment with the antioxidant $\alpha$-tocopherol prevents ROS production and alteration in the CD33 expression. NDGA and $\alpha$ tocopherol prevent ROS generation. $\alpha$-Tocopherol inhibits superoxide anion production by impairment of the NADPH oxidase assembly and inhibits p47phox translocation to the membrane [58]. Moreover, NDGA is a selective inhibitor of 12-lipoxygenase (12-LOX), which produces ROS during arachidonic acid metabolism. The mechanism by which ROS induced CD33 downregulation could be through the induction of inflammation, because IAA or $\mathrm{H}_{2} \mathrm{O}_{2}$ induces the inflammatory cytokine TNF- $\alpha$, and NDGA is a powerful antioxidant compound that affects a wide variety of cellular 


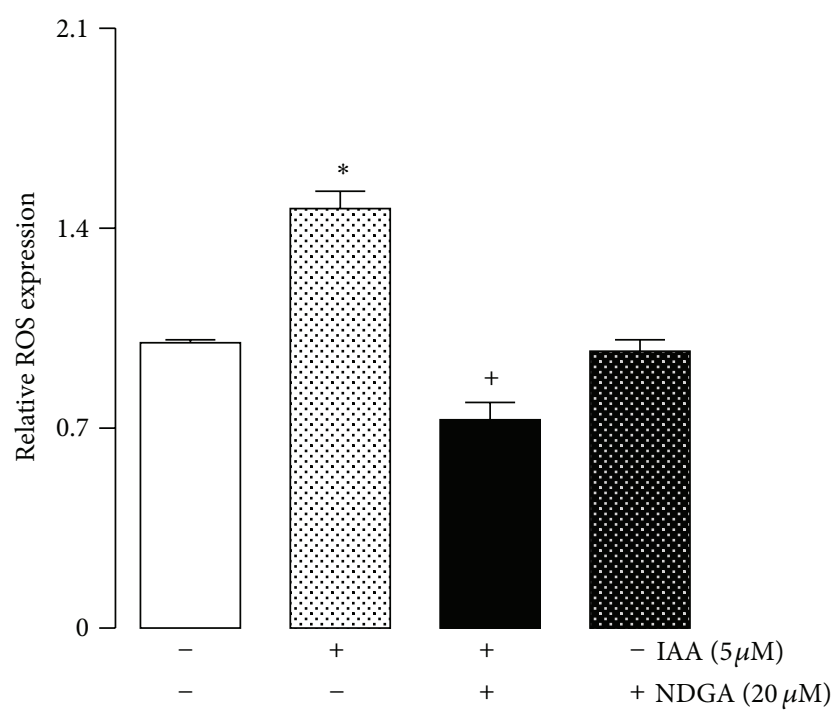

(a)

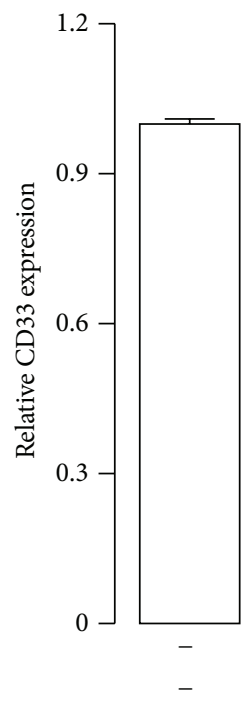

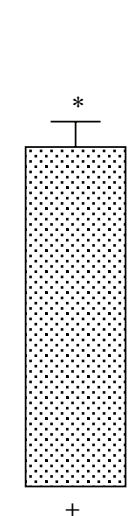

$+$

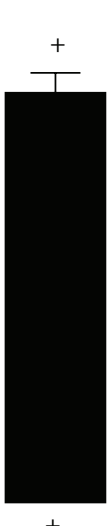

$+$

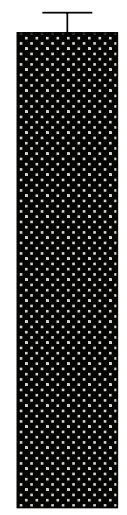

- IAA $(5 \mu \mathrm{M})$

$+\operatorname{NDGA}(20 \mu \mathrm{M})$
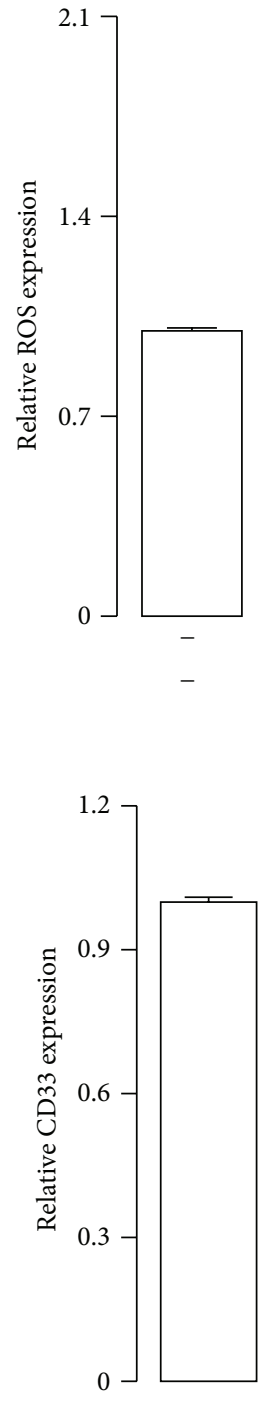

$-$

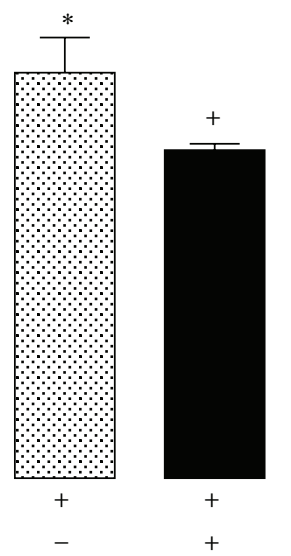

(b)

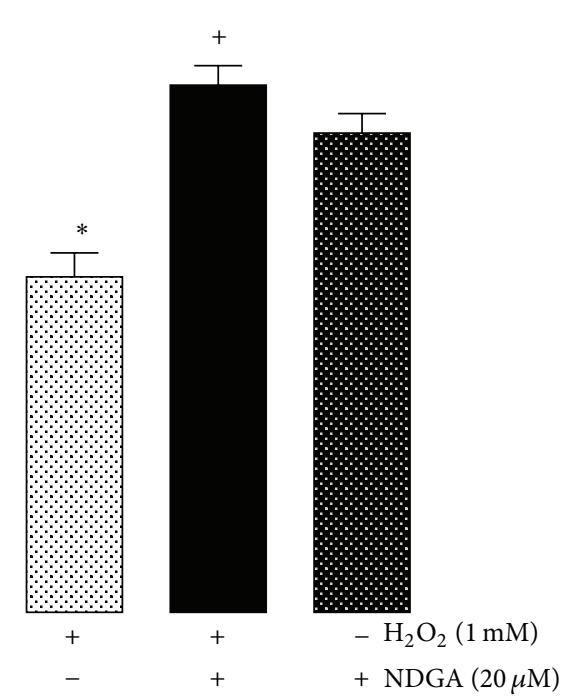

(d)

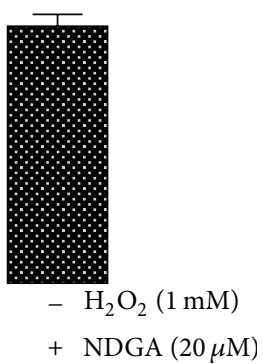

$+\operatorname{NDGA}(20 \mu \mathrm{M})$

(c)

Figure 7: Effect of NDGA on ((a), (c)) IAA or ((b), (d)) $\mathrm{H}_{2} \mathrm{O}_{2}$ induced increase of ((a), (b)) ROS levels and ((c), (d)) decrease of CD33 expression in MN. Cells were pretreated with vehicle or $20 \mu \mathrm{M}$ NDGA for $12 \mathrm{~h}$ before the addition of $5 \mu \mathrm{M} \mathrm{IAA}$ or $1 \mathrm{mM} \mathrm{H}_{2} \mathrm{O}_{2}$ and incubated for 72 and $48 \mathrm{~h}$, respectively. ROS levels detection and CD33 expression were determined by flow cytometry and expressed as index compared to control without treatment. Data are expressed as mean $\pm \mathrm{SEM} ; n=5 .{ }^{+} P<0.05$ versus control (without IAA or $\mathrm{H}_{2} \mathrm{O}_{2}$ ) and ${ }^{*} P<0.05$ versus control (without NDGA).

processes including TNF- $\alpha$. In this work, NDGA prevented the decrease in the expression of CD33 secondary to oxidative stress induced by $\mathrm{H}_{2} \mathrm{O}_{2}$ or IAA. These data suggest that alterations in $\mathrm{CD} 33$ secondary to oxidative conditions may be counteracted by exogenous antioxidants of different structure such as $\alpha$-tocopherol or NDGA. In addition, low concentration of NDGA may contribute to decreased oxidative stress by either scavenging ROS [4] and/or by the induction of Nrf2-dependent antioxidant enzymes $[9,11]$ and avoiding inflammation as inhibitor or COX-2 and LOX [39].

In conclusion, this study presents novel findings supporting the ameliorative effect of NDGA on the oxidant condition of human MNs. NDGA could prevent cell death under severe oxidative stress conditions. There was a slight increase of ROS production induced by $\mathrm{H}_{2} \mathrm{O}_{2}$ and IAA and a significant decrease of CD33 expression on MN surfaces. However, NDGA prevented these negative effects. These results suggest that changes in the redox state induced by hyperglycemia, IAA, or $\mathrm{H}_{2} \mathrm{O}_{2}$ generate an important signal that causes CD33 modulation in a negative manner, and this state might contribute to $\mathrm{MN}$ activation.

\section{Acknowledgments}

This study was supported partially by CONACYT Grants CB 2008-101948 and 129838 and PAPIIT IN129838. 


\section{References}

[1] S. Arteaga, A. Andrade-Cetto, and R. Cárdenas, "Larrea tridentata (Creosote bush), an abundant plant of Mexican and USAmerican deserts and its metabolite nordihydroguaiaretic acid," Journal of Ethnopharmacology, vol. 98, no. 3, pp. 231-239, 2005.

[2] S. Heron and E. Yarnell, "The safety of low-dose Larrea tridentata (DC) coville (Creosote Bush or Chaparral): a retrospective clinical study," Journal of Alternative and Complementary Medicine, vol. 7, no. 2, pp. 175-185, 2001.

[3] J. M. Lü, J. Nurko, S. M. Weakley et al., "Molecular mechanisms and clinical applications of nordihydroguaiaretic acid (NDGA) and its derivatives: an update," Medical Science Monitor, vol. 16, no. 5, pp. RA93-RA100, 2010.

[4] E. Floriano-Sánchez, C. Villanueva, O. N. Medina-Campos et al., "Nordihydroguaiaretic acid is a potent in vitro scavenger of peroxynitrite, singlet oxygen, hydroxyl radical, superoxide anion and hypochlorous acid and prevents in vivo ozoneinduced tyrosine nitration in lungs," Free Radical Research, vol. 40, no. 5, pp. 523-533, 2006.

[5] A. Galano, N. A. Macías-Ruvalcaba, O. N. M. Campos, and J. Pedraza-Chaverri, "Mechanism of the $\mathrm{OH}$ radical scavenging activity of nordihydroguaiaretic acid: a combined theoretical and experimental study," Journal of Physical Chemistry B, vol. 114, no. 19, pp. 6625-6635, 2010.

[6] D. W. Lee, I. S. Kwak, S. B. Lee et al., "Post-treatment effects of erythropoietin and nordihydroguaiaretic acid on recovery from cisplatin-induced acute renal failure in the rat," Journal of Korean medical science, vol. 24, supplement 1, pp. S170-S175, 2009.

[7] P. Yam-Canul, Y. I. Chirino, D. J. Sánchez-González et al., "Nordihydroguaiaretic acid attenuates potassium dichromateinduced oxidative stress and nephrotoxicity," Food and Chemical Toxicology, vol. 46, no. 3, pp. 1089-1096, 2008.

[8] S. González-Reyes, M. Orozco-Ibarra, S. Guzmán-Beltrán, E. Molina-Jijón, L. Massieu, and J. Pedraza-Chaverri, "Neuroprotective role of heme-oxygenase 1 againts iodoacetate-induced toxicity in rat cerebellar granule neurons: role of bilirubin," Free Radical Research, vol. 43, no. 3, pp. 214-223, 2009.

[9] S. Guzmán-Beltrán, S. Espada, M. Orozco-Ibarra, J. PedrazaChaverri, and A. Cuadrado, "Nordihydroguaiaretic acid activates the antioxidant pathway Nrf2/HO-1 and protects cerebellar granule neurons against oxidative stress," Neuroscience Letters, vol. 447, no. 2-3, pp. 167-171, 2008.

[10] N. Cárdenas-Rodríguez, S. Guzmán-Beltrán, O. N. MedinaCampos, M. Orozco-Ibarra, L. Massieu, and J. Pedraza-Chaverri, "The effect of nordihydroguaiaretic acid on iodoacetateinduced toxicity in cultured neurons," Journal of Biochemical and Molecular Toxicology, vol. 23, no. 2, pp. 137-142, 2009.

[11] A. I. Rojo, O. N. Medina-Campos, P. Rada et al., "Signaling pathways activated by the phytochemical nordihydroguaiaretic acid contribute to a Keap1-independent regulation of Nrf2 stability: role of glycogen synthase kinase-3," Free Radical Biology and Medicine, vol. 52, no. 2, pp. 473-487, 2012.

[12] B. Halliwell and G. Jmc, Free Radicals in Biology and Medicine, Oxford Press, New York. NY, USA, 2007.

[13] S. M. Deneke and B. L. Fanburg, "Regulation of cellular glutathione," American Journal of Physiology, vol. 257, no. 4, part 1, pp. L163-L173, 1989.

[14] C. Perricone, C. de Carolis, and R. Perricone, "Glutathione: a key player in autoimmunity," Autoimmunity Reviews, vol. 8, no. 8, pp. 697-701, 2009.
[15] I. Rahman and W. MacNee, "Regulation of redox glutathione levels and gene transcription in lung inflammation: therapeutic approaches," Free Radical Biology and Medicine, vol. 28, no. 9, pp. 1405-1420, 2000.

[16] S. Rahman, R. A. Ansari, H. Rehman, S. Parvez, and S. Raisuddin, "Nordihydroguaiaretic acid from creosote bush (Larrea tridentata) mitigates 12-O-tetradecanoylphorbol-13acetate-induced inflammatory and oxidative stress responses of tumor promotion cascade in mouse skin," Evidence-Based Complementary and Alternative Medicine, vol. 2011, Article ID 734785, 10 pages, 2011.

[17] R. A. Brumback, "Iodoacetate inhibition of glyceraldehyde-3phosphate dehydrogenase as a model of human myophosphorylase deficiency (McArdle's disease) and phosphofructokinase deficiency (Tarui's disease)," Journal of the Neurological Sciences, vol. 48, no. 3, pp. 383-398, 1980.

[18] K. Hernández-Fonseca, N. Cárdenas-Rodríguez, J. PedrazaChaverri, and L. Massieu, "Calcium-dependent production of reactive oxygen species is involved in neuronal damage induced during glycolysis inhibition in cultured hippocampal neurons," Journal of Neuroscience Research, vol. 86, no. 8, pp. 1768-1780, 2008.

[19] C. Nodin, C. Zhu, K. Blomgren, M. Nilsson, and F. Blomstrand, "Decreased oxidative stress during glycolytic inhibition enables maintenance of ATP production and astrocytic survival," Neurochemistry International, vol. 61, no. 3, pp. 291-301, 2012.

[20] J. Vaya, "Exogenous markers for the characterization of human diseases associated with oxidative stress," Biochimie. In press.

[21] Y. Koike, T. Hisada, M. Utsugi et al., "Glutathione redox regulates airway hyperresponsiveness and airway inflammation in mice," American Journal of Respiratory Cell and Molecular Biology, vol. 37, no. 3, pp. 322-329, 2007.

[22] S. Fritsch-Decker, T. Both, S. Mulhopt, H. R. Paur, C. Weiss, and S. Diabate, "Regulation of the arachidonic acid mobilization in macrophages by combustion-derived particles," Particle and Fibre Toxicology, vol. 8, article 23, 2011.

[23] M. Hayama, R. Inoue, S. Akiba, and T. Sato, "ERK and p38 MAP kinase are involved in arachidonic acid release induced by $\mathrm{H}_{2} \mathrm{O}_{2}$ and PDGF in mesangial cells," American Journal of Physiology, vol. 282, no. 3, pp. F485-F491, 2002.

[24] Y. Lu and L. M. Wahl, "Oxidative stress augments the production of matrix metalloproteinase-1, cyclooxygenase-2, and prostaglandin E2 through enhancement of NF- $\kappa$ B activity in lipopolysaccharide-activated human primary monocytes," Journal of Immunology, vol. 175, no. 8, pp. 5423-5429, 2005.

[25] S. Y. Kim, T. B. Kim, K. A. Moon et al., "Regulation of pro-inflammatory responses by lipoxygenases via intracellular reactive oxygen species in vitro and in vivo," Experimental and Molecular Medicine, vol. 40, no. 4, pp. 461-476, 2008.

[26] M. Morohoshi, K. Fujisawa, I. Uchimura, and F. Numano, "The effect of glucose and advanced glycosylation end products on IL-6 production by human monocytes," Annals of the New York Academy of Sciences, vol. 748, pp. 562-570, 1995.

[27] N. N. Orie, W. Zidek, and M. Tepel, "Increased intracellular generation of reactive oxygen species in mononuclear leukocytes from patients with diabetes mellitus type 2," Experimental and Clinical Endocrinology and Diabetes, vol. 108, no. 3, pp. 175-180, 2000.

[28] Y. Gonzalez, M. T. Herrera, G. Soldevila et al., "High glucose concentrations induce TNF- $\alpha$ production through the downregulation of CD33 in primary human monocytes," $B M C$ Immunology, vol. 13, article 19, 2012. 
[29] K. Lock, J. Zhang, J. Lu, S. H. Lee, and P. R. Crocker, "Expression of CD33-related siglecs on human mononuclear phagocytes, monocyte-derived dendritic cells and plasmacytoid dendritic cells," Immunobiology, vol. 209, no. 1-2, pp. 199-207, 2004.

[30] A. Boyum, "Isolation of lymphocytes, granulocytes and macrophages," Scandinavian Journal of Immunology, vol. 5, no. s5, pp. 9-15, 1976.

[31] J. Carmichael, W. G. DeGraff, and A. F. Gazdar, "Evaluation of a tetrazolium-based semiautomated colorimetric assay: assessment of chemosensitivity testing," Cancer Research, vol. 47, no. 4, pp. 936-942, 1987.

[32] I. Tommasini, P. Sestili, A. Guidarelli, and O. Cantoni, "Hydrogen peroxide generated at the level of mitochondria in response to peroxynitrite promotes U937 cell death via inhibition of the cytoprotective signalling mediated by cytosolic phospholipase A2," Cell Death and Differentiation, vol. 11, no. 9, pp. 974-984, 2004.

[33] A. Gomes, E. Fernandes, and J. L. F. C. Lima, "Fluorescence probes used for detection of reactive oxygen species," Journal of Biochemical and Biophysical Methods, vol. 65, no. 2-3, pp. 4580, 2005.

[34] I. Rahman, A. Kode, and S. K. Biswas, "Assay for quantitative determination of glutathione and glutathione disulfide levels using enzymatic recycling method," Nature Protocols, vol. 1, no. 6, pp. 3159-3165, 2007.

[35] T. W. Moody, J. Leyton, A. Martinez, S. Hong, A. Malkinson, and J. L. Mulshine, "Lipoxygenase inhibitors prevent lung carcinogenesis and inhibit non-small cell lung cancer growth," Experimental Lung Research, vol. 24, no. 4, pp. 617-628, 1998.

[36] S. Ansar, M. Iqbal, and M. Athar, "Nordihydroguairetic acid is a potent inhibitor of ferric-nitrilotriacetate-mediated hepatic and renal toxicity, and renal tumour promotion, in mice," Carcinogenesis, vol. 20, no. 4, pp. 599-606, 1999.

[37] M. Earashi, M. Noguchi, K. Kinoshita, and M. Tanaka, "Effects of eicosanoid synthesis inhibitors on the in vitro growth and prostaglandin $\mathrm{E}$ and leukotriene B secretion of a human breast cancer cell line," Oncology, vol. 52, no. 2, pp. 150-155, 1995.

[38] R. E. Carraway, S. Hassan, and D. E. Cochrane, "Regulation of neurotensin receptor function by the arachidonic acidlipoxygenase pathway in prostate cancer PC3 cells," Prostaglandins Leukotrienes and Essential Fatty Acids, vol. 74, no. 2, pp. 93-107, 2006.

[39] H. Salari, P. Braquet, and P. Borgeat, "Comparative effects of indomethacin, acetylenic acids, 15-HETE, nordihydroguaiaretic acid and BW755C on the metabolism of arachidonic acid in human leukocytes and platelets," Prostaglandins Leukotrienes and Medicine, vol. 13, no. 1, pp. 53-60, 1984.

[40] J. K. Huang, W. C. Chen, C. J. Huang et al., "Nordihydroguaiaretic acid-induced $\mathrm{Ca}^{2+}$ handling and cytotoxicity in human prostate cancer cells," Life Sciences, vol. 75, no. 19, pp. 2341-2351, 2004.

[41] J. Hofmanova, K. Soucek, J. Pachernik et al., "Lipoxygenase inhibitors induce arrest of tumor cells in S-phase of the cell cycle," Neoplasma, vol. 49, no. 6, pp. 362-367, 2002.

[42] K. Ono, K. Hasegawa, Y. Yoshiike, A. Takashima, M. Yamada, and H. Naiki, "Nordihydroguaiaretic acid potently breaks down pre-formed Alzheimer's $\beta$-amyloid fibrils in vitro," Journal of Neurochemistry, vol. 81, no. 3, pp. 434-440, 2002.

[43] Y. Goodman, M. R. Steiner, S. M. Steiner, and M. P. Mattson, "Nordihydroguaiaretic acid protects hippocampal neurons against amyloid $\beta$-peptide toxicity, and attenuates free radical and calcium accumulation," Brain Research, vol. 654, no. 1, pp. 171-176, 1994.

[44] A. Pludie;ddemann, S. Mukhopadhyay, and S. Gordon, "Innate immunity to intracellular pathogens: macrophage receptors and responses to microbial entry," Immunological Reviews, vol. 240, no. 1, pp. 11-24, 2011.

[45] M. Valko, D. Leibfritz, J. Moncol, M. T. D. Cronin, M. Mazur, and J. Telser, "Free radicals and antioxidants in normal physiological functions and human disease," International Journal of Biochemistry and Cell Biology, vol. 39, no. 1, pp. 44-84, 2007.

[46] W. Dröge, "Free radicals in the physiological control of cell function," Physiological Reviews, vol. 82, no. 1, pp. 47-95, 2002.

[47] A. Murakami and H. Ohigashi, "Targeting NOX, INOS and COX-2 in inflammatory cells: chemoprevention using food phytochemicals," International Journal of Cancer, vol. 121, no. 11, pp. 2357-2363, 2007.

[48] A. Zúñiga-Toalá, E. Tapia, C. Zazueta et al., "Nordihydroguaiaretic acid pretreatment prevents ischemia and reperfusion induced renal injury, oxidant stress and mitochondrial alterations," Journal of Medicinal Plants Research, vol. 6, no. 15, pp. 473-487, 2012.

[49] S. J. Orr, N. M. Morgan, R. J. Buick et al., "SOCS3 targets Siglec 7 for proteasomal degradation and blocks siglec 7-mediated responses," The Journal of Biological Chemistry, vol. 282, no. 6, pp. 3418-3422, 2007.

[50] K. Shamsasenjan, K. I. Otsuyama, S. Abroun et al., "IL-6induced activation of MYC is responsible for the down-regulation of CD33 expression in CD33(+) myeloma cells," International Journal of Hematology, vol. 89, no. 3, pp. 310-318, 2009.

[51] F. Lajaunias, J. M. Dayer, and C. Chizzolini, "Constitutive repressor activity of $\mathrm{CD} 33$ on human monocytes requires sialic acid recognition and phosphoinositide 3-kinase-mediated intracellular signaling," European Journal of Immunology, vol. 35, no. 1, pp. 243-251, 2005.

[52] R. Deopurkar, H. Ghanim, J. Friedman et al., "Differential effects of cream, glucose, and orange juice on inflammation, endotoxin, and the expression of toll-like receptor-4 and suppressor of cytokine signaling-3," Diabetes Care, vol. 33, no. 5, pp. 991-997, 2010.

[53] H. Ghanim, C. L. Sia, M. Upadhyay et al., "Orange juice neutralizes the proinflammatory effect of a high-fat, highcarbohydrate meal and prevents endotoxin increase and tolllike receptor expression," American Journal of Clinical Nutrition, vol. 91, no. 4, pp. 940-949, 2010.

[54] N. Nakao, T. Kurokawa, T. Nonami, G. Tumurkhuu, N. Koide, and T. Yokochi, "Hydrogen peroxide induces the production of tumor necrosis factor- $\alpha$ in RAW 264.7 macrophage cells via activation of p38 and stress-activated protein kinase," Innate Immunity, vol. 14, no. 3, pp. 190-196, 2008.

[55] R. Ruiz-Ramos, L. Lopez-Carrillo, A. D. Rios-Perez, A. de Vizcaya-Ruíz, and M. E. Cebrian, "Sodium arsenite induces ROS generation, DNA oxidative damage, $\mathrm{HO}-1$ and c-Myc proteins, $\mathrm{NF}-\kappa \mathrm{B}$ activation and cell proliferation in human breast cancer MCF-7 cells," Mutation Research, vol. 674, no. 1-2, pp. 109-115, 2009.

[56] D. Pessler-Cohen, P. Pekala, J. Kovsan, A. Bloch-Damti, A. Rudich, and N. Bashan, "GLUT4 repression in response to oxidative stress is associated with reciprocal alterations in $\mathrm{C} / \mathrm{EBP} \alpha$ and delta isoforms in 3T3-L1 adipocytes," Archives of Physiology and Biochemistry, vol. 112, no. 1, pp. 3-12, 2006.

[57] D. D. Harrison-Findik, D. Schafer, E. Klein et al., "Alcohol metabolism-mediated oxidative stress down-regulates hepcidin 
transcription and leads to increased duodenal iron transporter expression," The Journal of Biological Chemistry, vol. 281, no. 32, pp. 22974-22982, 2006.

[58] O. Cachia, J. E. Benna, E. Pedruzzi, B. Descomps, M. A. Gougerot-Pocidalo, and C. L. Leger, " $\alpha$-tocopherol inhibits the respiratory burst in human monocytes: attenuation of $\mathrm{p} 47^{\text {phox }}$ membrane translocation and phosphorylation," The Journal of Biological Chemistry, vol. 273, no. 49, pp. 32801-32805, 1998. 


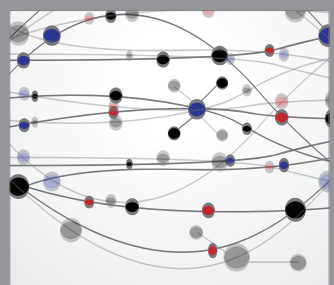

The Scientific World Journal
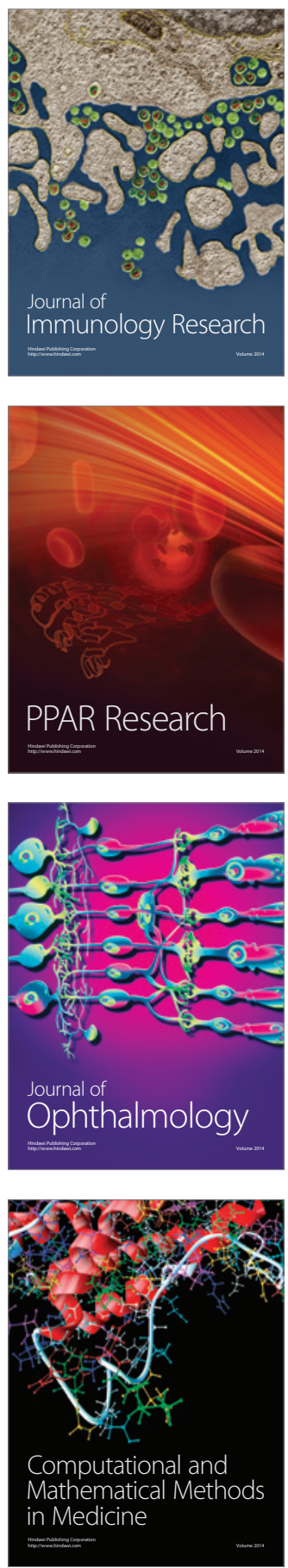

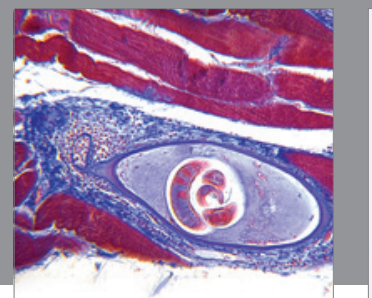

Gastroenterology

Research and Practice
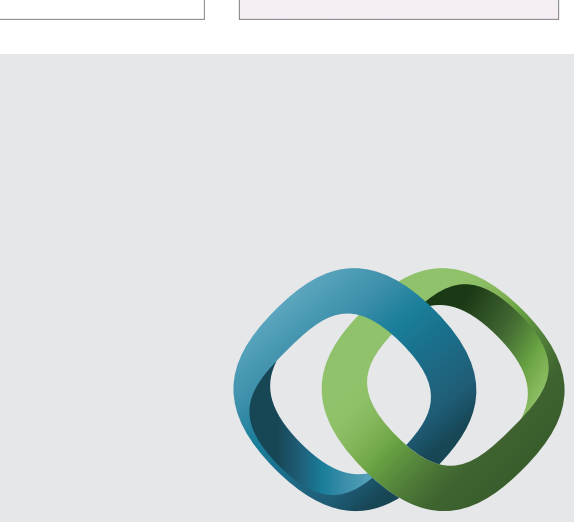

\section{Hindawi}

Submit your manuscripts at

http://www.hindawi.com
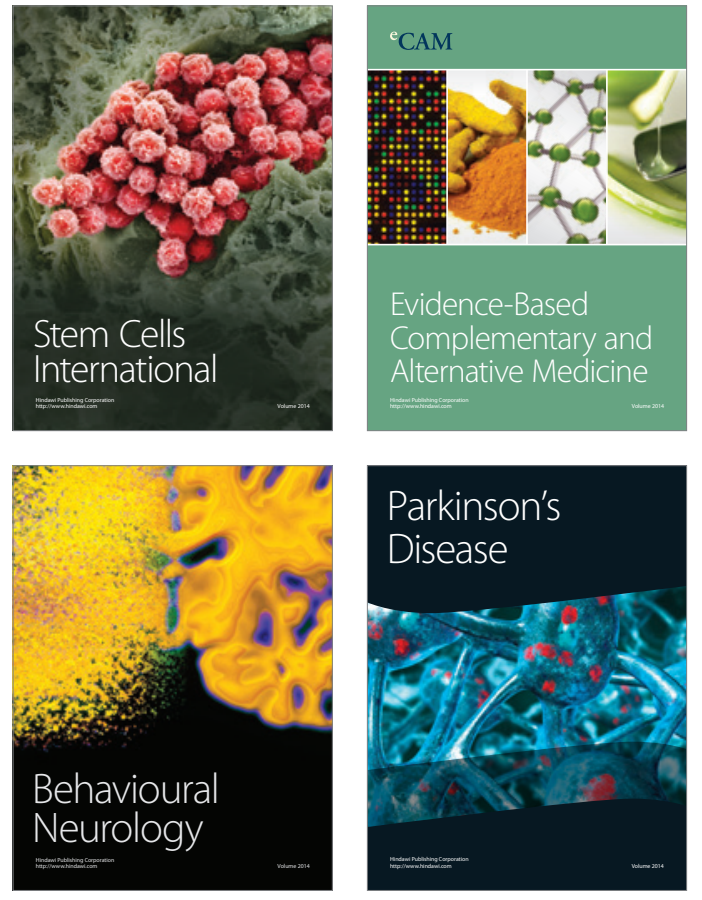
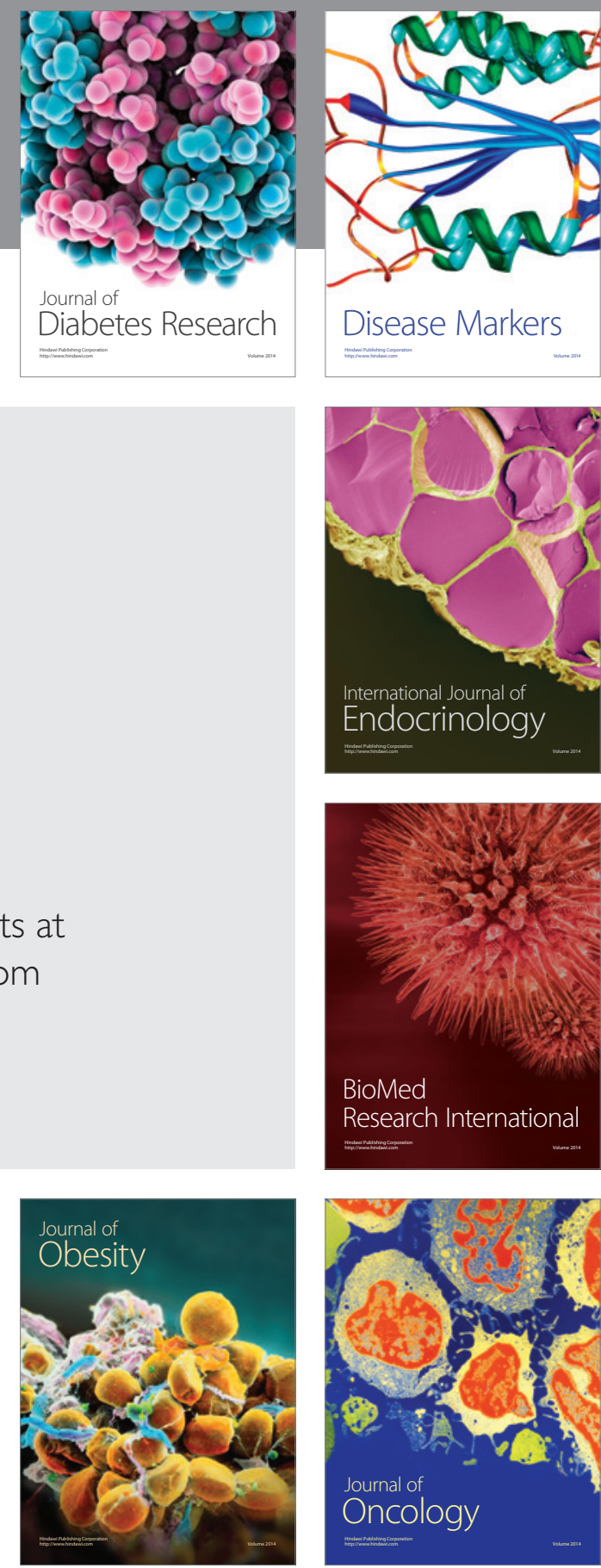

Disease Markers
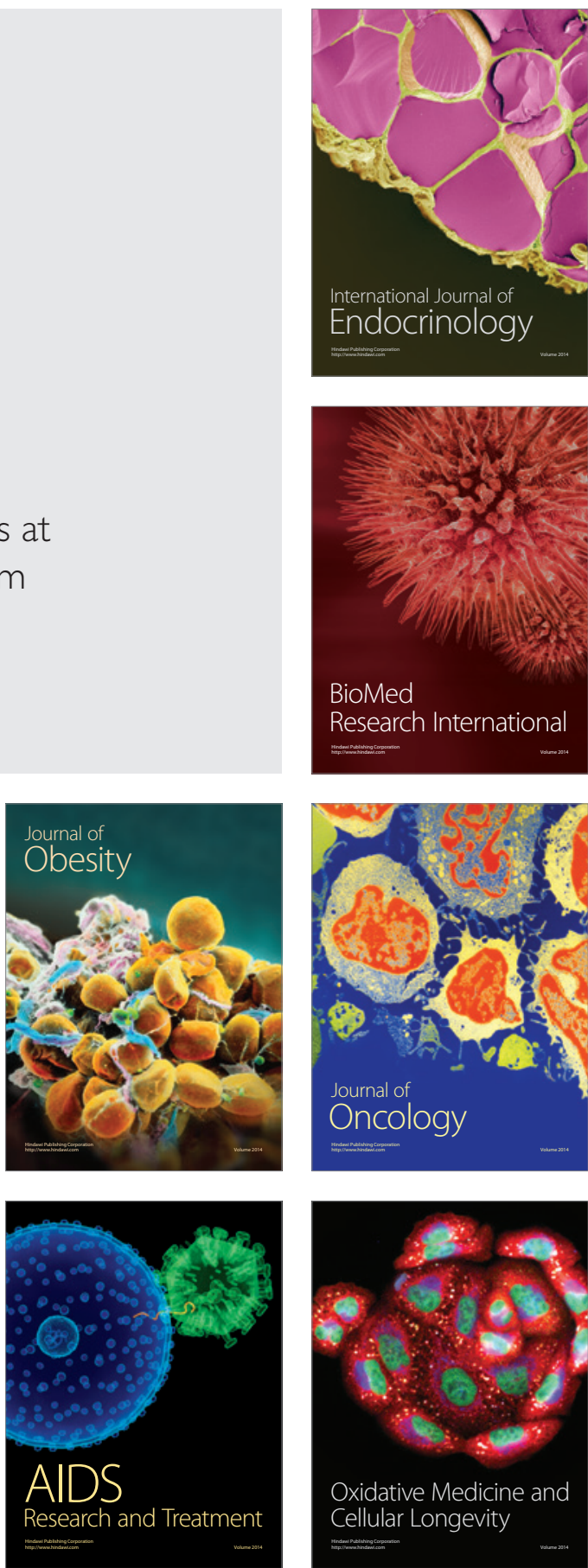